\title{
LEVEL II SCOUR ANALYSIS FOR BRIDGE 125 (MIDBUS00070125) on US ROUTE 7, crossing the MIDDLEBURY RIVER, MIDDLEBURY, VERMONT
}

U.S. Geological Survey Open-File Report 97-103

Prepared in cooperation with

VERMONT AGENCY OF TRANSPORTATION and

FEDERAL HIGHWAY ADMINISTRATION 


\section{LEVEL II SCOUR ANALYSIS FOR BRIDGE 125 (MIDBUS00070125) on US ROUTE 7, crossing the MIDDLEBURY RIVER, MIDDLEBURY, VERMONT}

By Erick M. Boehmler and Robert H. Flynn

U.S. Geological Survey Open-File Report 97-103

Prepared in cooperation with

VERMONT AGENCY OF TRANSPORTATION and

FEDERAL HIGHWAY ADMINISTRATION 


\title{
U.S. DEPARTMENT OF THE INTERIOR BRUCE BABBITT, Secretary
}

\author{
U.S. GEOLOGICAL SURVEY \\ Gordon P. Eaton, Director
}

For additional information write to:

District Chief

U.S. Geological Survey 361 Commerce Way

Pembroke, NH 03275-3718
Copies of this report may be purchased from:

U.S. Geological Survey

Branch of Information Services

Open-File Reports Unit

Box 25286

Denver, CO 80225-0286 


\section{CONTENTS}

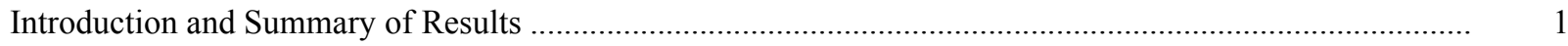

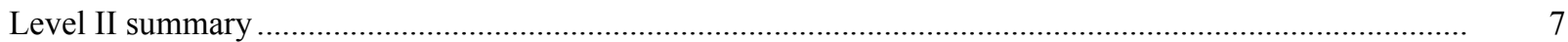

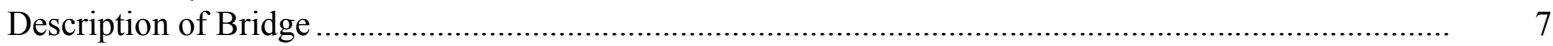

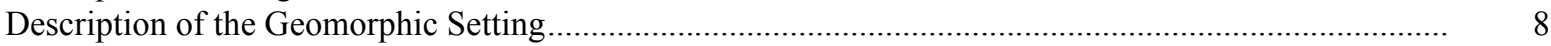

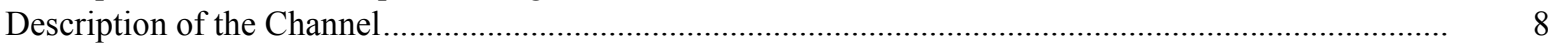

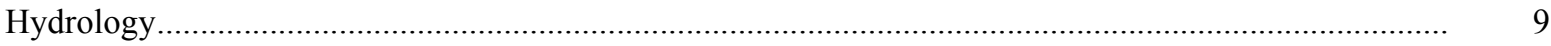

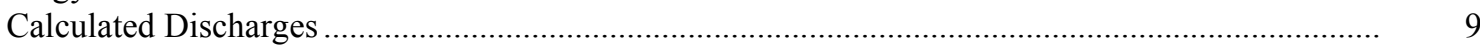

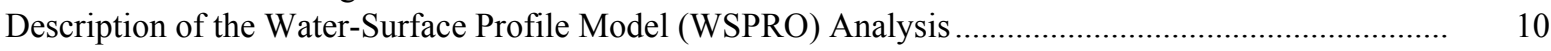

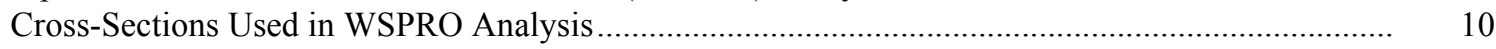

Data and Assumptions Used in WSPRO Model ...................................................................... 11

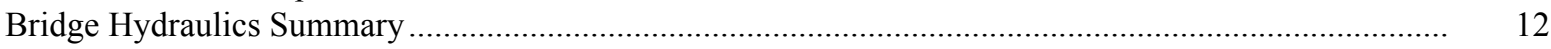

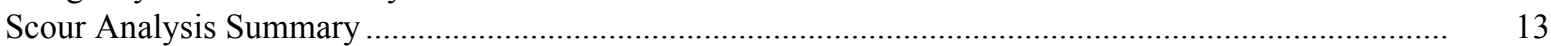

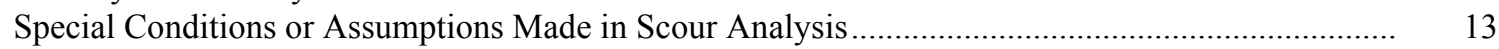

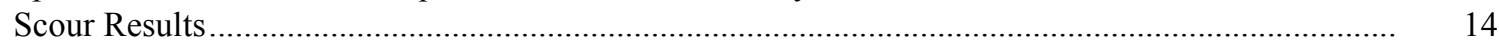

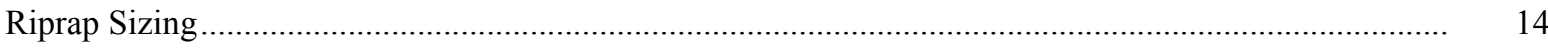

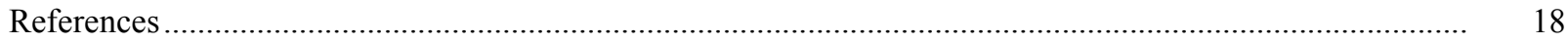

Appendixes:

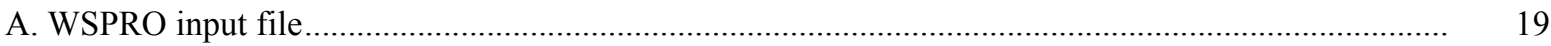

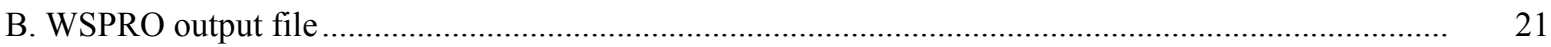

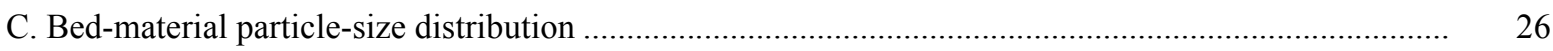

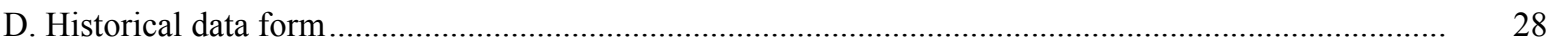

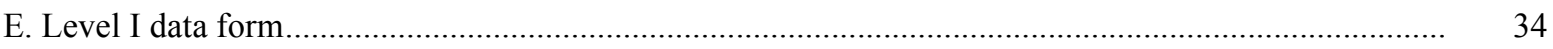

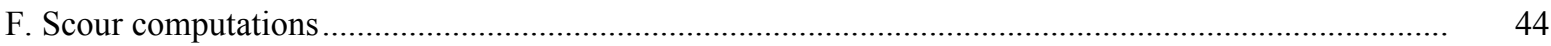

\section{FIGURES}

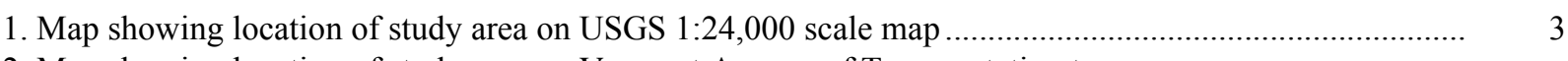

2. Map showing location of study area on Vermont Agency of Transportation town

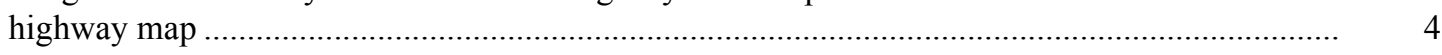

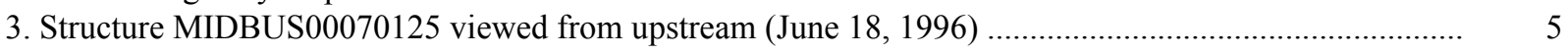

4. Downstream channel viewed from structure MIDBUS00070125 (June 18, 1996)............................... 5

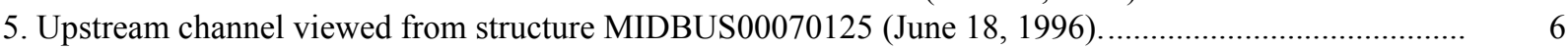

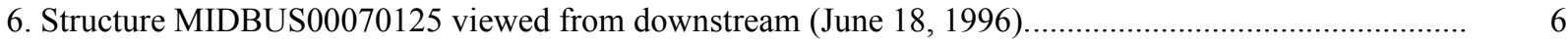

7. Water-surface profiles for the 100- and 500-year discharges at structure

MIDBUS00070125 on U.S. Route 7, crossing the Middlebury River,

Middlebury, Vermont.

8. Scour elevations for the 100- and 500-year discharges at structure

MIDBUS00070125 on U.S. Route 7, crossing the Middlebury River,

Middlebury, Vermont.

\section{TABLES}

1. Remaining footing/pile depth at abutments for the 100-year discharge at structure

MIDBUS00070125 on U.S. Route 7, crossing the Middlebury River,

Middlebury, Vermont.

2. Remaining footing/pile depth at abutments for the 500-year discharge at structure

MIDBUS00070125 on U.S. Route 7, crossing the Middlebury River,

Middlebury, Vermont. 


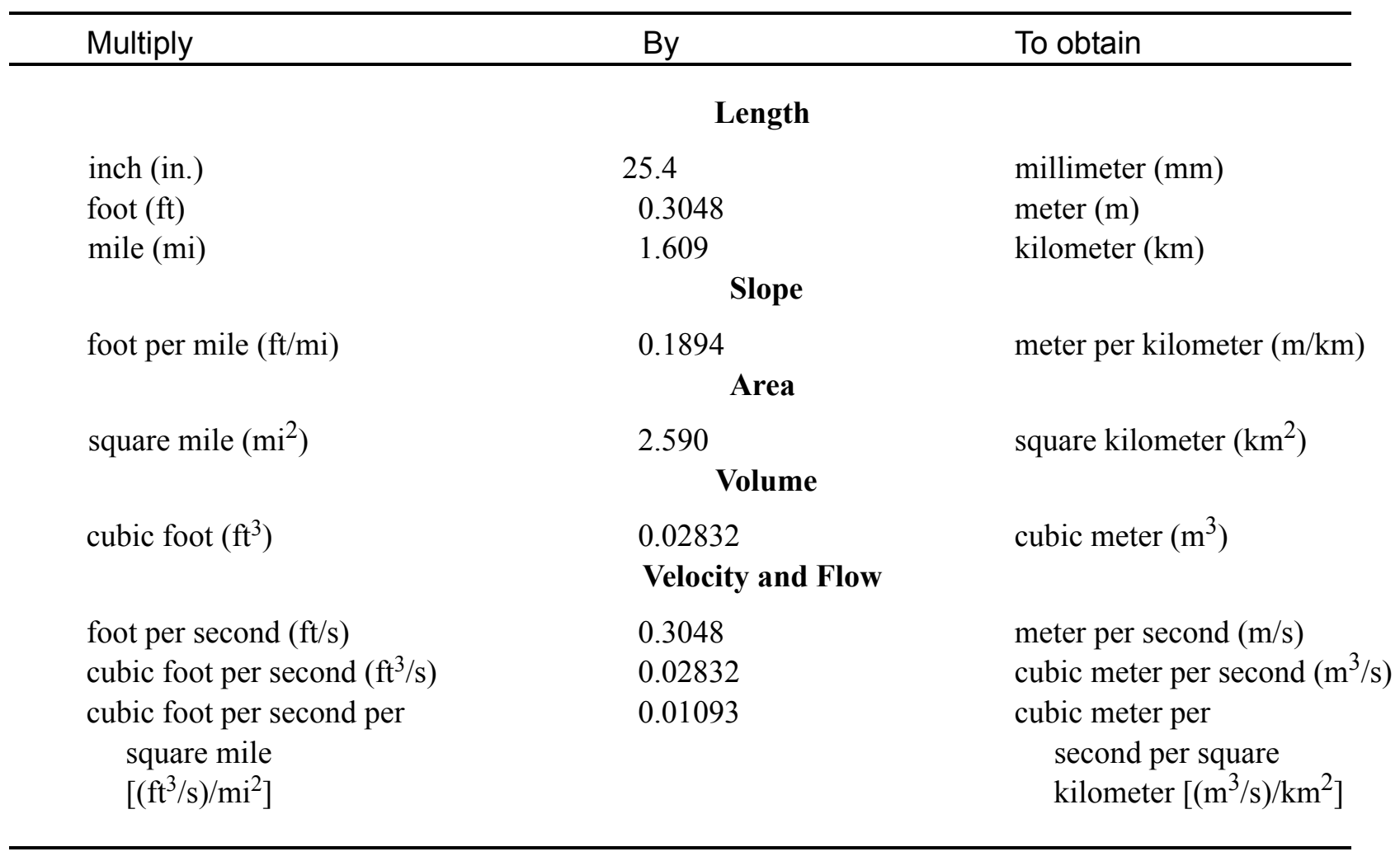

\section{OTHER ABBREVIATIONS}

$\begin{array}{lrlr}\mathrm{BF} & \text { bank full } & \text { LWW } & \text { left wingwall } \\ \mathrm{cfs} & \text { cubic feet per second } & \text { MC } & \text { main channel } \\ \mathrm{D}_{50} & \text { median diameter of bed material } & \text { RAB } & \text { right abutment } \\ \mathrm{DS} & \text { downstream } & \text { RABUT } & \text { face of right abutment } \\ \mathrm{elev} & \text { elevation } & \text { RB } & \text { right bank } \\ \mathrm{f} / \mathrm{p} & \text { flood plain } & \text { ROB } & \text { right overbank } \\ \mathrm{ft}^{2} & \text { square feet } & \text { RWW } & \text { right wingwall } \\ \mathrm{ft} / \mathrm{ft} & \text { feet per foot } & \text { TH } & \text { town highway } \\ \mathrm{JCT} & \text { junction } & \text { UB } & \text { under bridge } \\ \mathrm{LAB} & \text { left abutment } & \text { US } & \text { upstream } \\ \mathrm{LABUT} & \text { face of left abutment } & \text { USGS } & \text { United States Geological Survey } \\ \mathrm{LB} & \text { left bank } & \text { VTAOT Vermont Agency of Transportation } \\ \mathrm{LOB} & \text { left overbank } & \text { WSPRO } & \text { water-surface profile model }\end{array}$

In this report, the words "right" and "left" refer to directions that would be reported by an observer facing downstream. Sea level: In this report, "sea level" refers to the National Geodetic Vertical Datum of 1929-- a geodetic datum derived from a general adjustment of the first-order level nets of the United States and Canada, formerly called Sea Level Datum of 1929.

In the appendices, the above abbreviations may be combined. For example, USLB would represent upstream left bank. 


\title{
LEVEL II SCOUR ANALYSIS FOR BRIDGE 125 (MIDBUS00070125) ON U.S. ROUTE 7, CROSSING THE MIDDLEBURY RIVER, MIDDLEBURY, VERMONT
}

\author{
By Erick M. Boehmler and Robert H. Flynn
}

\section{INTRODUCTION AND SUMMARY OF RESULTS}

This report provides the results of a detailed Level II analysis of scour potential at structure MIDBUS00070125 on U.S. Route 7 crossing the Middlebury River, Middlebury, Vermont (figures 1-8). A Level II study is a basic engineering analysis of the site, including a quantitative analysis of stream stability and scour (U.S. Department of Transportation, 1993). Results of a Level I scour investigation also are included in Appendix E of this report. A Level I investigation provides a qualitative geomorphic characterization of the study site. Information on the bridge, gleaned from Vermont Agency of Transportation (VTAOT) files, was compiled prior to conducting Level I and Level II analyses and is found in Appendix D.

The site is in the Green Mountain section of the New England physiographic province in west-central Vermont. The 46.8- $\mathrm{mi}^{2}$ drainage area is in a predominantly rural and forested basin. In the vicinity of the study site, the surface cover consists of row crops on the right overbank upstream and downstream, and trees on the left overbank.

In the study area, the Middlebury River has a straight channel with a slope of approximately $0.005 \mathrm{ft} / \mathrm{ft}$, an average channel top width of $77 \mathrm{ft}$ and an average channel depth of $4 \mathrm{ft}$. The predominant channel bed materials are sand and cobbles with a median grain size $\left(\mathrm{D}_{50}\right)$ of $59.4 \mathrm{~mm}(0.195 \mathrm{ft})$. The geomorphic assessment at the time of the Level I and Level II site visit on June 18, 1996, indicated that the reach was stable.

The U.S. Route 7 crossing of the Middlebury River is a 202-ft-long, two-lane bridge consisting of one 91-foot, and two 55-foot steel-beam spans (Vermont Agency of Transportation, written communication, December 14, 1995). The bridge is supported by vertical, concrete abutment walls with spill-through embankments. The channel is skewed approximately 45 degrees to the opening while the opening-skew-to-roadway is 45 degrees.

The scour protection measures at the site were type-2 stone fill (less than 36 inches diameter) on the spill-through embankments of each abutment and type- 1 stone fill (less than 12 inches diameter) on the right bank upstream. Additional details describing conditions at the site are included in the Level II Summary and Appendices D and E. 
Scour depths and rock rip-rap sizes were computed using the general guidelines described in Hydraulic Engineering Circular 18 (Richardson and others, 1995). Total scour at a highway crossing is comprised of three components: 1) long-term streambed degradation; 2) contraction scour (due to accelerated flow caused by a reduction in flow area at a bridge) and; 3) local scour (caused by accelerated flow around piers and abutments). Total scour is the sum of the three components. Equations are available to compute depths for contraction and local scour and a summary of the results of these computations follows.

Contraction scour for all modelled flows ranged from 0.0 to $1.2 \mathrm{ft}$. The worst-case contraction scour occurred at the 500-year discharge. Abutment scour ranged from 7.5 to $11.0 \mathrm{ft}$. The worst-case abutment scour occurred at the 500-year discharge at the left abutment. Pier scour ranged from 8.3 to $15.9 \mathrm{ft}$. for each modeled discharge. The worst-case pier scour occurred at the 500-year discharge. In this report, piers are numerically designated " 1 " and " 2 " for the left and right piers respectively. Additional information on scour depths and depths to armoring are included in the section titled "Scour Results". Scoured-streambed elevations, based on the calculated scour depths, are presented in tables 1 and 2. A cross-section of the scour computed at the bridge is presented in figure 8. Scour depths were calculated assuming an infinite depth of erosive material and a homogeneous particle-size distribution.

It is generally accepted that the Froehlich equation (abutment scour) gives "excessively conservative estimates of scour depths" (Richardson and others, 1995, p. 47). Usually, computed scour depths are evaluated in combination with other information including (but not limited to) historical performance during flood events, the geomorphic stability assessment, existing scour protection measures, and the results of the hydraulic analyses. Therefore, scour depths adopted by VTAOT may differ from the computed values documented herein. 


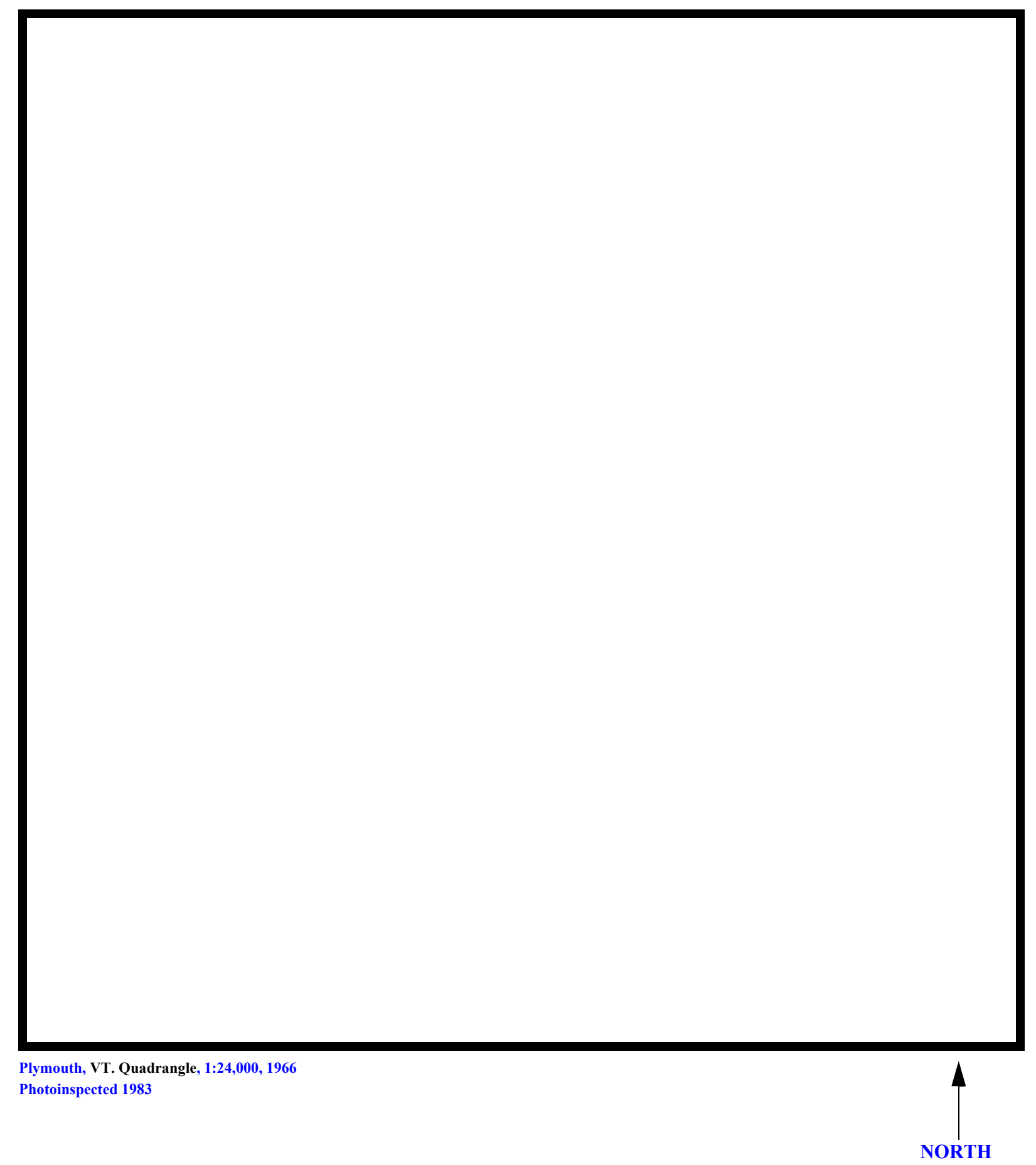

Figure 1. Location of study area on USGS 1:24,000 scale map. 
Figure 2. Location of study area on Vermont Agency of Transportation town highway map. 

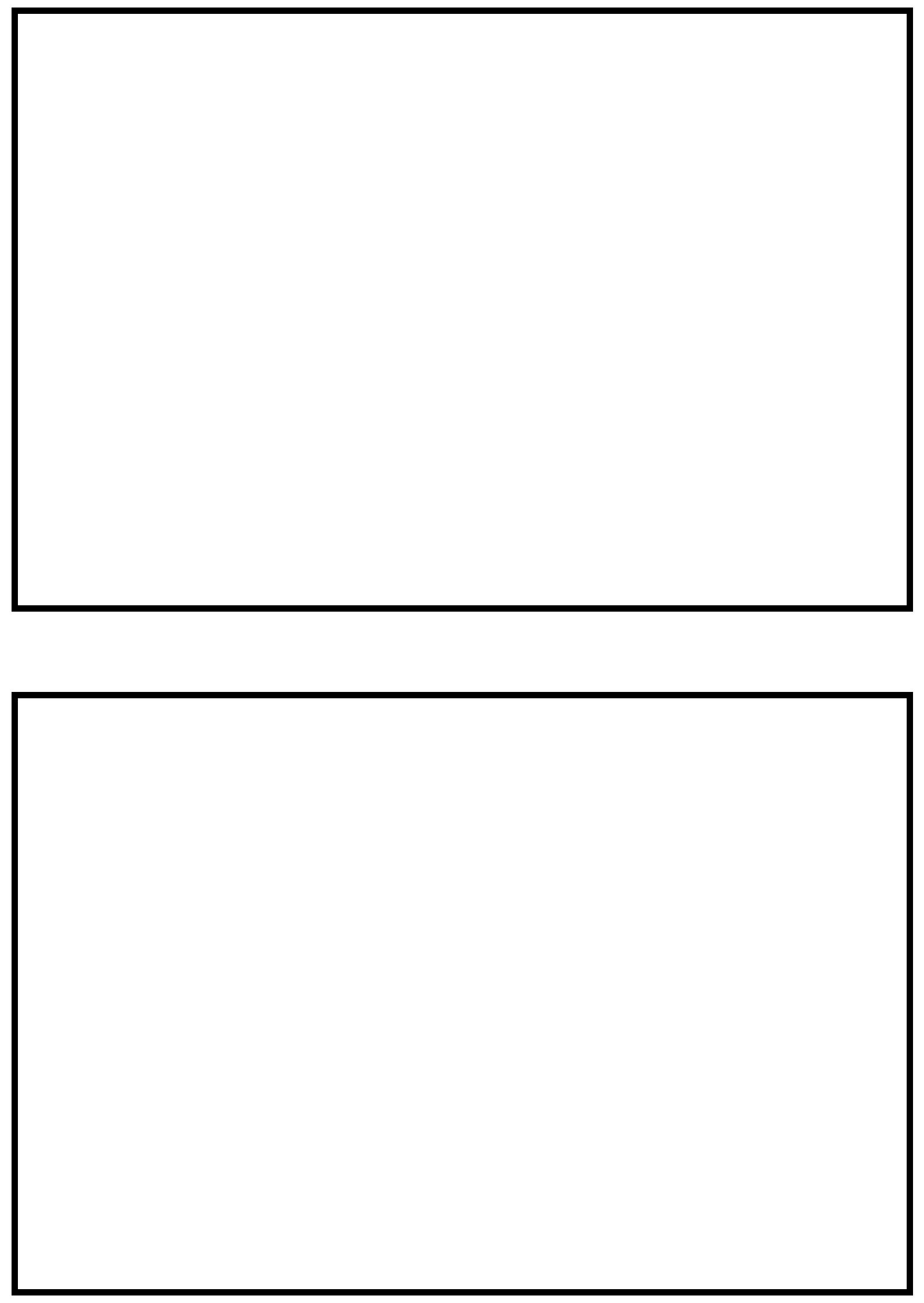

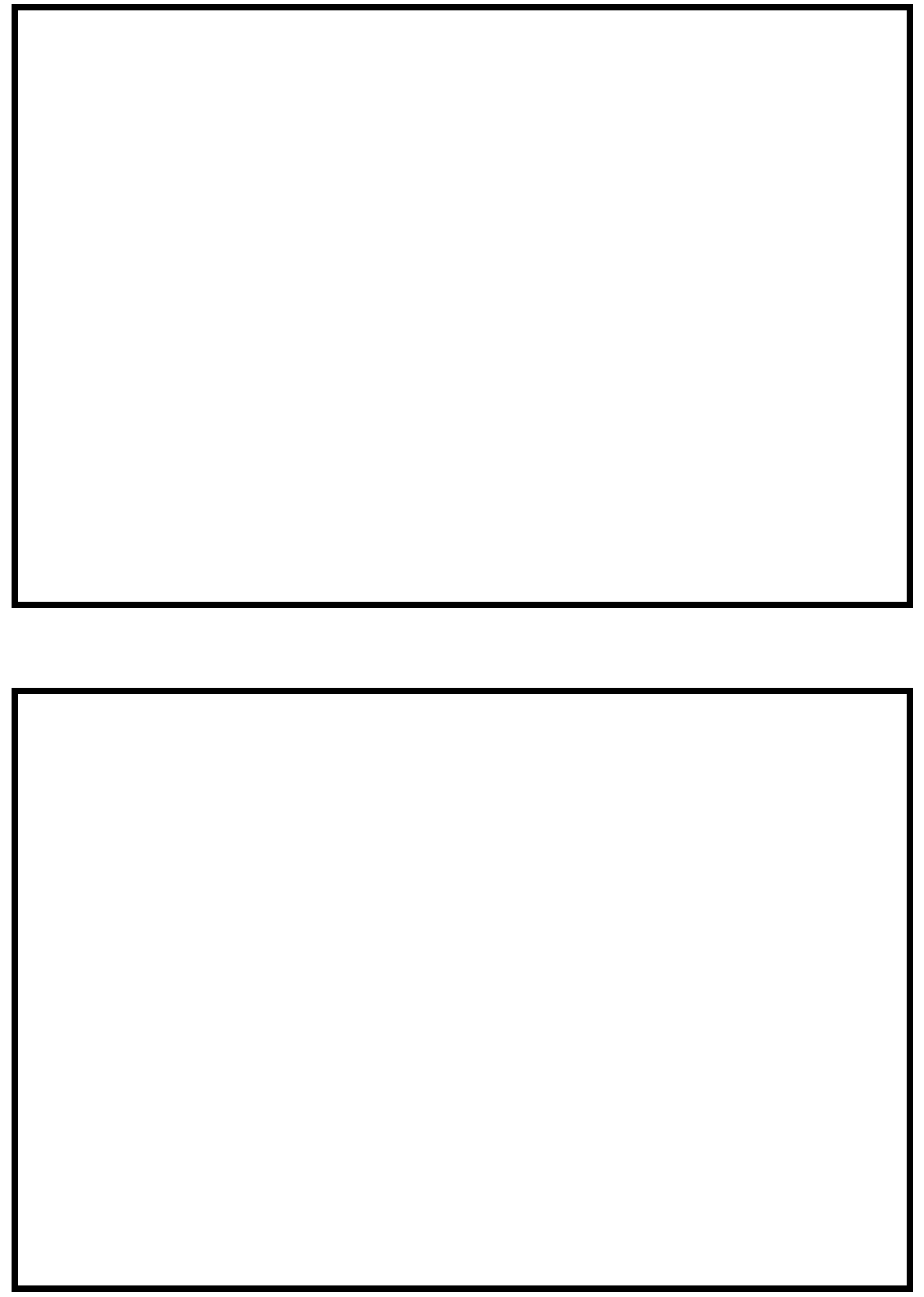


\section{LEVEL II SUMMARY}

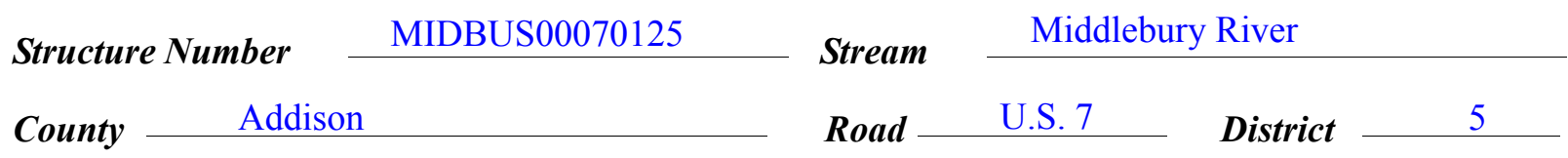

\section{Description of Bridge}

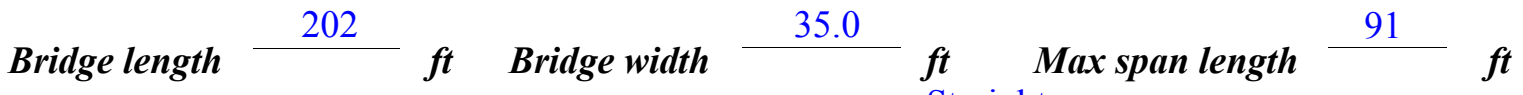
Alignment of bridge to road (on curve or straight) Spill-through Abutment type

Stone fill on abutment? Yes

\section{Embankment type} Straight

nammintinu af atan a fil Type-2 is noted on the spill-through embankments of each abutment Sloping 6/18/96 and type-1 is noted on the right bank upstream.

Abutments and piers are concrete. The piers are solid concrete walls (as opposed to multiple columns) with rounded ends aligned with the flow direction.

Yes 45

Is bridge skewed to flood flow according to Yes ' survey? Angle

There is a mild channel bend at the bridge.

Debris accumulation on bridge at time of Level I or Level II site visit:

Date of insnortion $6 / 18 / 96$

Level I

$$
6 / 18 / 96
$$

Percent of anchel
blocked verticatty blocked inortzontatly

0 0

Level II

Moderate. There is some debris accumulation (dead trees and branches) on the left overbank upstream.

Potential for debris

None evident on 6/18/96. 


\section{Description of the Geomorphic Setting}

General topography The channel is located in a low relief valley setting, with irregular flood plains and moderately sloping valley walls on both sides.

Geomorphic conditions at bridge site: downstream (DS), upstream (US)

Date of inspection $\quad 6 / 18 / 96$

DS left: $\quad$ Steep channel bank to a narrow overbank.

DS right: $\quad$ Moderately sloping channel bank to a wide flood plain.

US left: $\quad$ Moderately sloping channel bank to a narrow overbank.

US right: $\quad$ Steep channel bank to a wide flood plain.

\section{Description of the Channel}

\begin{tabular}{|c|c|c|c|}
\hline \multirow[b]{2}{*}{ Average top width } & \multirow[b]{2}{*}{ Sand / Cobbles } & \multirow[b]{2}{*}{ Average depth } & \multirow{2}{*}{$\frac{4}{\text { Sand / Cobbles }} \underset{f t}{ }$} \\
\hline & & & \\
\hline Predominant bed material & & Bank material & Straight and stable \\
\hline with semi-alluvial boundaries. & $\cdots$. & ". $\cdot$ & \\
\hline
\end{tabular}

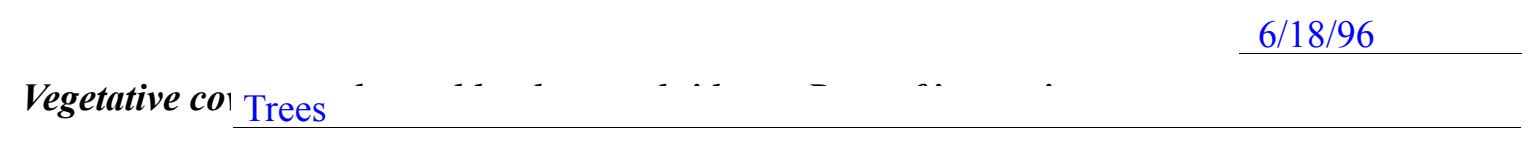

DS left: $\quad$ Trees with brush and row crops on the flood plain.

DS right: $\quad$ Trees

US left: $\quad$ Trees with pasture and row crops on the flood plain.

US right: $\quad$ Yes

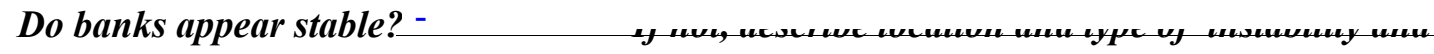

date of observatton.

None evident on

6/18/96.

Describe any obstructions in channel and date of observation. 


\section{Hydrology}

Drainage area $\quad \frac{46.8}{\boldsymbol{m i}^{2}}$

Percentage of drainage area in physiographic provinces: (approximate)

Physiographic province/section New England / Green Mountain
Percent of drainage area 100

Is drainage area considered rural or urban? Rural Describe any significant urbanization:

Is there a USGS gage on the stream of interest?

No

$-$

\section{USGS gage description}

USGS gage number

Gage drainage area $\mathrm{mi}^{2}$

No

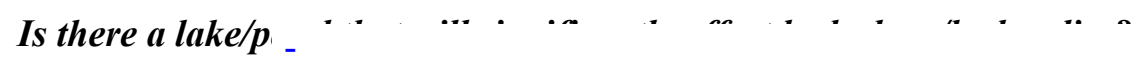

\section{Q100 $\quad \mathrm{ft}^{3} / \mathrm{s}$}

The 100- and 500-year discharges are based on

discharge frequency curves computed by use of several empirical equations (Benson, 1962;

FHWA, 1983; Johnson and Tasker, 1974; Potter, $1957 \mathrm{a} \& b$; and Talbot, 1887) and that provided in the VTAOT database. The values of the 100- and 500-year discharge from the VTAOT discharge frequency curve were selected for the hydraulic analyses at this site due to their central tendency with the values from the other curves. 


\section{Description of the Water-Surface Profile Model (WSPRO) Analysis}

Datum for WSPRO analysis (USGS survey, sea level, VTAOT plans)

USGS survey

Datum tie between USGS survey and VTAOT plans

Subtract 117.1 feet from the

USGS arbitrary survey datum to obtain the VTAOT plans' datum.

Description of reference marks used to determine USGS datum. $\quad \underline{\mathrm{RM} 1 \text { is the center of an }}$

engraved triangle on a brass tablet on top of the concrete left abutment at the upstream end (elev.

$503.59 \mathrm{ft}$, arbitrary survey datum). RM2 is the center point of a chiseled "X" on top of the

concrete right abutment at the downstream end (elev. $501.32 \mathrm{ft}$, arbitrary survey datum).

\section{Cross-Sections Used in WSPRO Analysis}

\begin{tabular}{cccl}
\hline${ }^{1}$ Cross-section & $\begin{array}{c}\text { Section } \\
\text { Reference } \\
\text { Distance } \\
\text { (SRD) in feet }\end{array}$ & $\begin{array}{c}{ }^{2} \text { Cross-section } \\
\text { development }\end{array}$ & \multicolumn{1}{c}{ Comments } \\
\hline EXITX & -200 & 1 & $\begin{array}{l}\text { Exit section } \\
\text { Downstream Full-valley } \\
\text { section (Templated from } \\
\text { EXITX) }\end{array}$ \\
BRIDG & 0 & 2 & $\begin{array}{l}\text { Bridge section } \\
\text { RDWAY }\end{array}$ \\
APPRO & 24 & 1 & $\begin{array}{l}\text { Road Grade section } \\
\text { Modelled Approach sec- } \\
\text { tion (Templated from } \\
\text { APTEM) } \\
\text { APTEM }\end{array}$ \\
& 187 & 2 & $\begin{array}{l}\text { Approach section as sur- } \\
\text { veyed (Used as a tem- } \\
\text { plate) }\end{array}$ \\
\hline
\end{tabular}

${ }^{1}$ For location of cross-sections see plan-view sketch included with Level I field form, Appendix E. For more detail on how cross-sections were developed see WSPRO input file. 


\section{Data and Assumptions Used in WSPRO Model}

Hydraulic analyses of the reach were done by use of the Federal Highway Administration's WSPRO step-backwater computer program (Shearman and others, 1986, and Shearman, 1990). The analyses reported herein reflect conditions existing at the site at the time of the study. Furthermore, in the development of the model it was necessary to assume no accumulation of debris or ice at the site. Results of the hydraulic model are presented in the Bridge Hydraulic Summary, Appendix B, and figure 7.

Channel roughness factors (Manning's " $n$ ") used in the hydraulic model were estimated using field inspections at each cross section following the general guidelines described by Arcement and Schneider (1989). Final adjustments to the values were made during the modelling of the reach. Channel " $\mathrm{n}$ " values for the reach ranged from 0.035 to 0.050 , and overbank " $\mathrm{n}$ " values ranged from 0.035 to 0.060 .

Normal depth at the exit section (EXITX) was assumed as the starting water surface. This depth was computed by use of the slope-conveyance method outlined in the user's manual for WSPRO (Shearman, 1990). The slope used was $0.0047 \mathrm{ft} / \mathrm{ft}$ which was estimated from the topographic map (U.S. Geological Survey, 1944).

The surveyed approach section (APTEM) was moved along the approach channel slope $(0.0061 \mathrm{ft} / \mathrm{ft})$ to establish the modelled approach section (APPRO), one bridge length upstream of the upstream face as recommended by Shearman and others (1986). This approach also provides a consistent method for determining scour variables. 


\section{Bridge Hydraulics Summary}

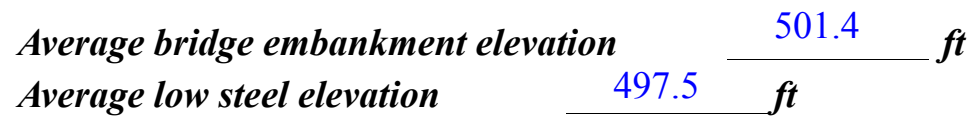

$$
\text { 100-year discharge } \quad 6,000 \quad \mathrm{ft}^{3} / \mathrm{s}
$$

Water-surface elevation in bridge opening $\quad 491.5 \quad f t$

Road overtopping? ___ No Discharge over road ___ -- $\quad, t^{3} / s$

\begin{tabular}{llll} 
Area of flow in bridge opening & $740 \quad \boldsymbol{f t}^{2}$ \\
\cline { 2 - 3 } Average velocity in bridge opening & 8.1 & $\boldsymbol{f t} / \mathrm{s}$
\end{tabular}

$\begin{array}{llll}\text { Maximum WSPRO tube velocity at bridge } & 9.8 \mathrm{ft} / \mathrm{s}\end{array}$

Water-surface elevation at Approach section with bridge 493.6

$\begin{array}{ll}\text { Water-surface elevation at Approach section without bridge } & 492.7\end{array}$

Amount of backwater caused by bridge $\quad 0.9$ it

500-year discharge $\quad 8,500 \quad \mathrm{ft}^{3} / \mathrm{s}$

Water-surface elevation in bridge opening $\quad 491.8 \mathrm{ft}$

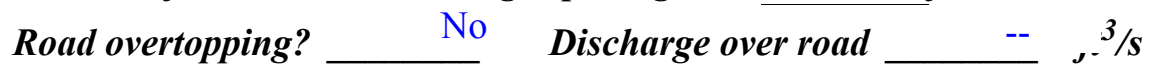

$\begin{array}{llll}\text { Area of flow in bridge opening } & 768 \quad \boldsymbol{f t}^{2} & \\ \text { Average velocity in bridge opening } & & 11.1 \quad \mathrm{ft} / \mathrm{s}\end{array}$

Maximum WSPRO tube velocity at bridge 13.4 's

Water-surface elevation at Approach section with bridge 495.5

Water-surface elevation at Approach section without bridge $\quad 493.6$

Amount of backwater caused by bridge 1.9 .

Incipient overtopping discharge ___ -- $\mathrm{ft}^{3} / \mathrm{s}$

Water-surface elevation in bridge opening $\quad--\quad t$

Area of flow in bridge opening _ -- $\mathrm{ft}^{2}$

Average velocity in bridge opening __ -- $f t / s$

Maximum WSPRO tube velocity at bridge $\quad--\quad f t / s$

Water-surface elevation at Approach section with bridge

Water-surface elevation at Approach section without bridge

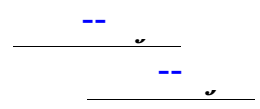

Amount of backwater caused by bridge _ 


\section{Scour Analysis Summary}

\section{Special Conditions or Assumptions Made in Scour Analysis}

Scour depths were computed using the general guidelines described in Hydraulic Engineering Circular 18 (Richardson and others, 1995). Scour depths were calculated assuming an infinite depth of erosive material and a homogeneous particle-size distribution. The results of the scour analysis are presented in tables 1 and 2 and a graph of the scour depths is presented in figure 8 .

Contraction scour was computed by use of the clear-water contraction scour equation (Richardson and others, 1995, p. 32, equation 20). For contraction scour computations, the average depth in the contracted section (AREA/TOPWIDTH) is subtracted from the depth of flow computed by the scour equation (Y2) to determine the actual amount of scour. The depths of armoring computed suggest that streambed armoring will not impede contraction scour.

Abutment scour for the left abutment was computed by use of the Froehlich equation (Richardson and others, 1995, p. 48, equation 28). Variables for the Froehlich equation include the Froude number of the flow approaching the embankments, the length of the embankment blocking flow, and the depth of flow approaching the embankment less any roadway overtopping.

Scour at the right abutment for the 100- and 500-year discharges was computed by use of the HIRE equation (Richardson and others, 1995, p. 49, equation 29) because the HIRE equation is recommended when the length to depth ratio of the embankment blocking flow exceeds 25 . The variables used by the HIRE abutment-scour equation are defined the same as those defined for the Froehlich abutment-scour equation.

Because the influence of scour processes on the spill-through embankment material is uncertain, the scour depth at the vertical concrete abutment walls is unknown. Therefore, the total scour depths computed at the toe of each spill-through embankment were applied for the entire area of each embankment as shown in figure 8.

Pier scour was computed by use of a modified equation developed at Colorado State University (Richardson and others, 1995, p. 36, equation 21) for all discharges modeled. Variables for the pier scour equation include pier length, pier width, average depth and maximum velocity (for the froude number) immediately upstream of the bridge, and four correction factors for pier shape, flow attack angle, streambed-form, and streambed armoring. Computed pier scour depths were below the bottom of the pier footing only at pier 1. 


\section{Scour Results}

100-yr discharge 500-yr discharge

Contraction scour:

(Scour depths in feet)

Main channel

Live-bed scour

Clear-water scour

Depth to armoring

Left overbank

Right overbank

Local scour:

Abutment scour

Left abutment

8.3

11.0

9.6-

7.5-

Right abutment

Pier scour

Pier 1

13.9

15.9

8.3

Pier 2

Pier 3

Abutments:

Left abutment

Right abutment

Piers:

Pier 1

Pier 2

\section{Riprap Sizing}

overtopping

discharge

Incipient 


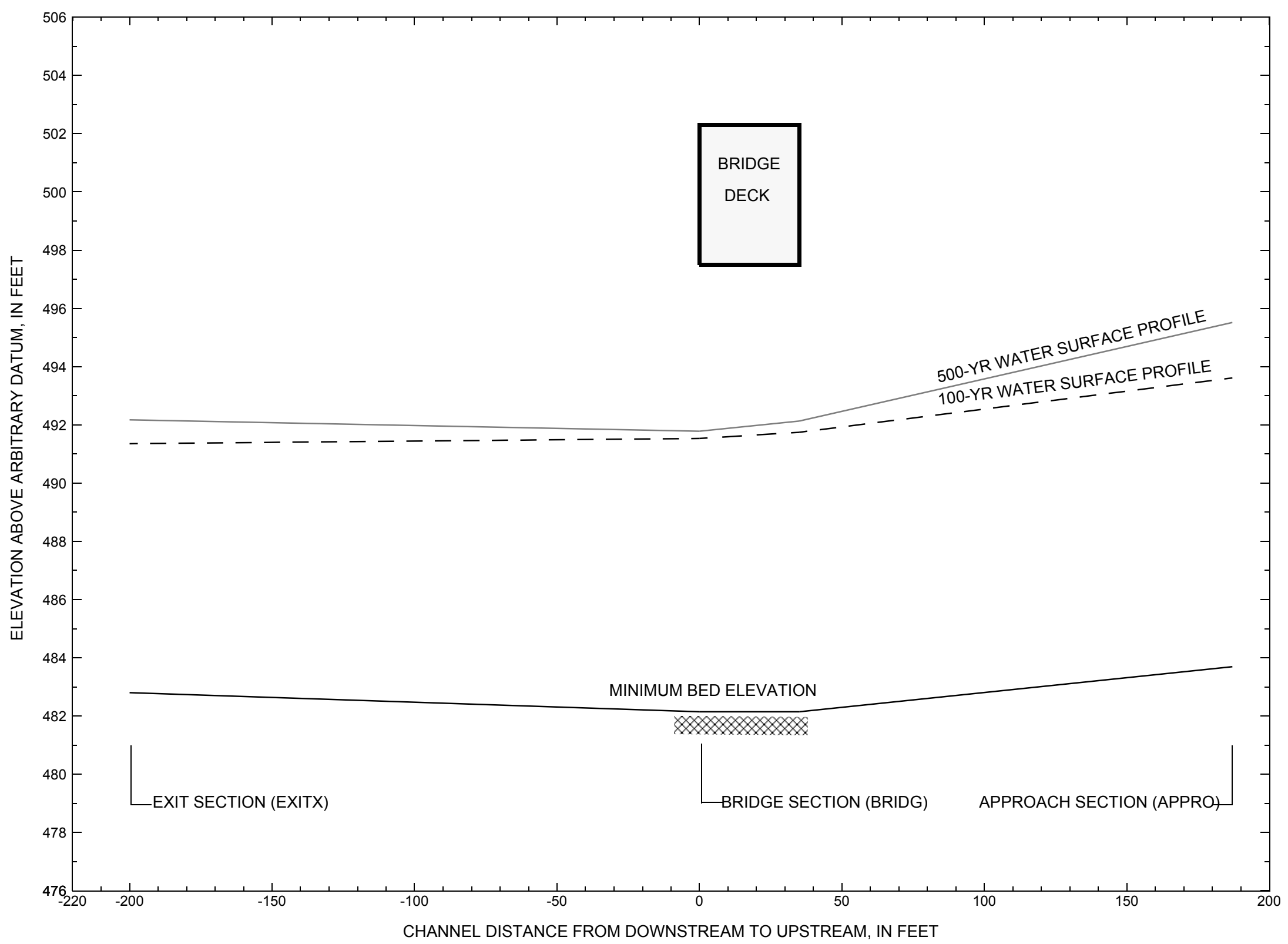

Figure 7. Water-surface profiles for the 100- and 500-yr discharges at structure MIDBUS00070125 on U.S. Route 7, crossing Middlebury River, Middlebury, Vermont. 


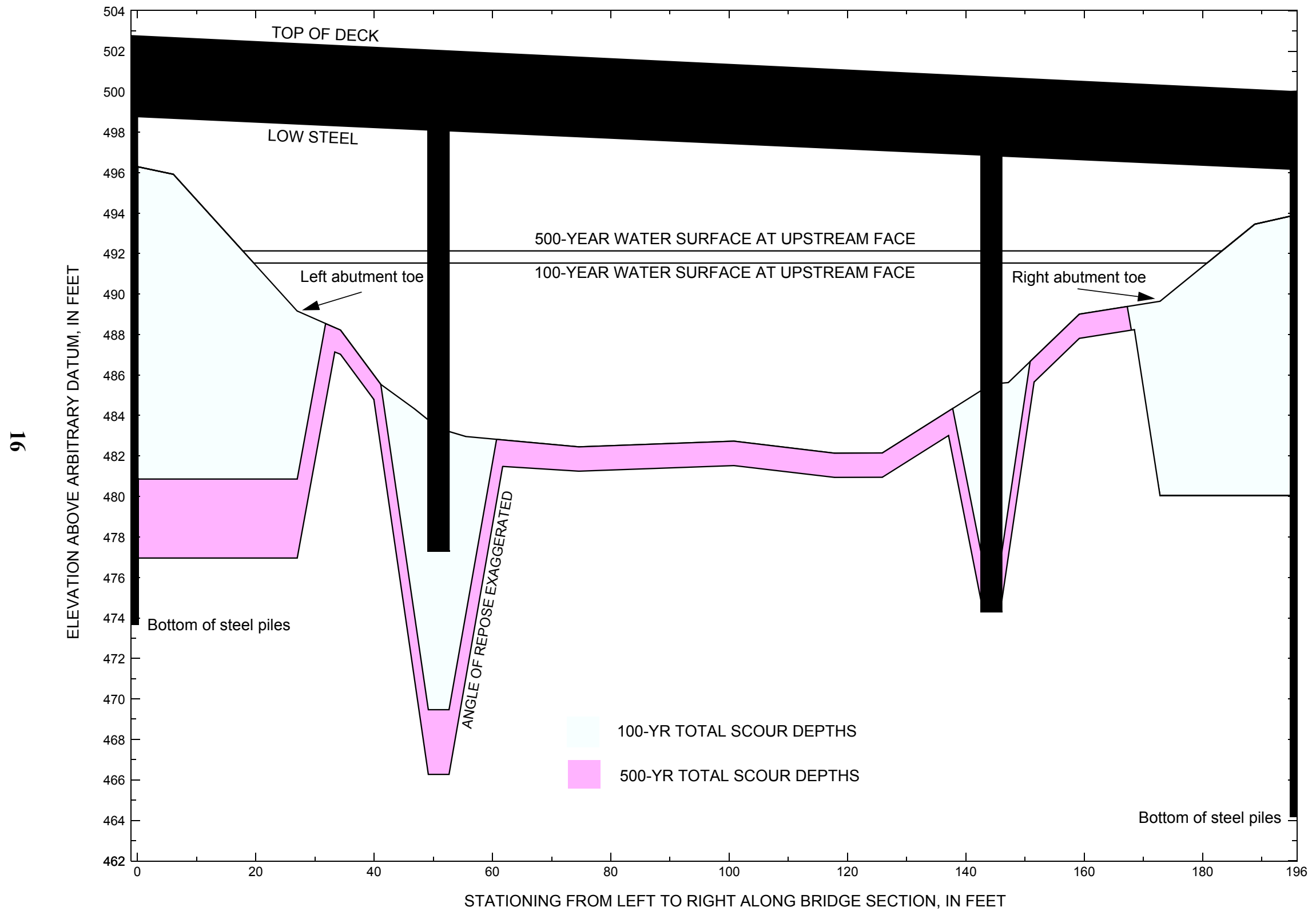

Figure 8. Scour elevations for the 100-yr and 500-yr discharges at structure MIDBUS00070125 on U.S. Route 7, crossing Middlebury River, Middlebury, Vermont. 


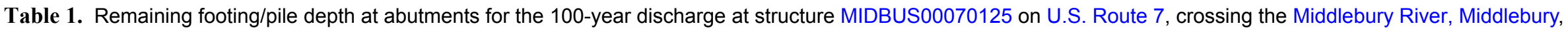
Vermont.

[VTAOT, Vermont Agency of Transportation; --,no data]

\begin{tabular}{|c|c|c|c|c|c|c|c|c|c|c|c|}
\hline Description & Station $^{1}$ & $\begin{array}{c}\text { VTAOT } \\
\text { Bridge seat } \\
\text { elevation } \\
\text { (feet) }\end{array}$ & $\begin{array}{c}\text { Surveyed } \\
\text { Low cord } \\
\text { elevation } \\
\text { (feet) }\end{array}$ & $\begin{array}{c}\text { Bottom of } \\
\text { footing/pile } \\
\text { elevation }{ }^{2} \\
\text { (feet) }\end{array}$ & $\begin{array}{l}\text { Channel } \\
\text { elevation at } \\
\text { abutment/ } \\
\text { pier }^{2} \\
\text { (feet) }\end{array}$ & $\begin{array}{l}\text { Contraction } \\
\text { scour depth } \\
\text { (feet) }\end{array}$ & $\begin{array}{l}\text { Abutment } \\
\text { scour } \\
\text { depth } \\
\text { (feet) }\end{array}$ & $\begin{array}{l}\text { Pier } \\
\text { scour } \\
\text { depth } \\
\text { (feet) }\end{array}$ & $\begin{array}{l}\text { Depth of } \\
\text { total scour } \\
\text { (feet) }\end{array}$ & $\begin{array}{c}\text { Elevation of } \\
\text { scour }^{2} \\
\text { (feet) }\end{array}$ & $\begin{array}{c}\text { Remaining } \\
\text { footing/pile } \\
\text { depth } \\
\text { (feet) }\end{array}$ \\
\hline \multicolumn{12}{|c|}{100 -yr. discharge is 6,000 cubic-feet per second } \\
\hline Left abutment & 0.0 & 381.7 & 498.8 & 473.7 & 496.3 & -- & -- & -- & -- & -- & 7.2 \\
\hline Left abutment toe & 27.0 & -- & -- & -- & 489.2 & 0.0 & 8.3 & -- & 8.3 & 480.9 & -- \\
\hline Pier 1 & 50.9 & 380.4 & 497.9 & 477.3 & 483.4 & 0.0 & -- & 13.9 & 13.9 & 469.5 & -7.8 \\
\hline Pier 2 & 144.3 & 379.2 & 496.8 & 474.3 & 485.5 & 0.0 & -- & 8.3 & 8.3 & 477.2 & 2.9 \\
\hline Right abutment toe & 172.8 & -- & -- & -- & 489.6 & 0.0 & 9.6 & -- & 9.6 & 480.0 & -- \\
\hline Right abutment & 194.9 & 379.1 & 496.2 & 464.2 & 493.8 & -- & -- & -- & -- & -- & 15.8 \\
\hline
\end{tabular}

1.Measured along the face of the most constricting side of the bridge.

2.Arbitrary datum for this study.

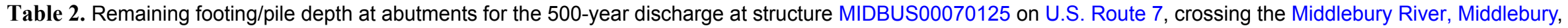
Vermont.

[VTAOT, Vermont Agency of Transportation; --, no data]

\begin{tabular}{|c|c|c|c|c|c|c|c|c|c|c|c|}
\hline Description & Station $^{1}$ & $\begin{array}{c}\text { VTAOT } \\
\text { Bridge seat } \\
\text { elevation } \\
\text { (feet) }\end{array}$ & $\begin{array}{l}\text { Surveyed } \\
\text { Low cord } \\
\text { elevation } \\
\text { (feet) }\end{array}$ & $\begin{array}{c}\text { Bottom of } \\
\text { footing/pile } \\
\text { elevation }{ }^{2} \\
\text { (feet) }\end{array}$ & $\begin{array}{c}\text { Channel } \\
\text { elevation at } \\
\text { abutment/ } \\
\text { pier }^{2} \\
\text { (feet) }\end{array}$ & $\begin{array}{l}\text { Contraction } \\
\text { scour depth } \\
\text { (feet) }\end{array}$ & $\begin{array}{l}\text { Abutment } \\
\text { scour } \\
\text { depth } \\
\text { (feet) }\end{array}$ & $\begin{array}{l}\text { Pier } \\
\text { scour } \\
\text { depth } \\
\text { (feet) }\end{array}$ & $\begin{array}{l}\text { Depth of } \\
\text { total scour } \\
\text { (feet) }\end{array}$ & $\begin{array}{c}\text { Elevation of } \\
\text { scour }^{2} \\
\text { (feet) }\end{array}$ & $\begin{array}{c}\text { Remaining } \\
\text { footing/pile } \\
\text { depth } \\
\text { (feet) }\end{array}$ \\
\hline \multicolumn{12}{|c|}{500 -yr. discharge is 8,500 cubic-feet per second } \\
\hline Left abutment & 0.0 & 381.7 & 498.8 & 473.7 & 496.3 & -- & -- & -- & -- & -- & 3.3 \\
\hline Left abutment toe & 27.0 & -- & -- & -- & 489.2 & 1.2 & 11.0 & -- & 12.2 & 477.0 & -- \\
\hline Pier 1 & 50.9 & 380.4 & 497.9 & 477.3 & 483.4 & 1.2 & -- & 15.9 & 17.1 & 466.3 & -11.0 \\
\hline Pier 2 & 144.3 & 379.2 & 496.8 & 474.3 & 485.5 & 1.2 & -- & 9.5 & 10.7 & 474.8 & 0.5 \\
\hline Right abutment toe & 172.8 & -- & -- & -- & 489.6 & 1.2 & 7.5 & -- & 8.7 & 480.9 & -- \\
\hline Right abutment & 194.9 & 379.1 & 496.2 & 464.2 & 493.8 & -- & -- & -- & -- & -- & 16.7 \\
\hline
\end{tabular}

1.Measured along the face of the most constricting side of the bridge.

2.Arbitrary datum for this study. 


\section{SELECTED REFERENCES}

Arcement, G.J., Jr., and Schneider, V.R., 1989, Guide for selecting Manning's roughness coefficients for natural channels and flood plains: U.S. Geological Survey Water-Supply Paper 2339, 38 p.

Barnes, H.H., Jr., 1967, Roughness characteristics of natural channels: U.S. Geological Survey Water-Supply Paper 1849,213 p.

Benson, M. A., 1962, Factors Influencing the Occurrence of Floods in a Humid Region of Diverse Terrain: U.S. Geological Survey WaterSupply Paper 1580-B, 64 p.

Brown, S.A. and Clyde, E.S., 1989, Design of riprap revetment: Federal Highway Administration Hydraulic Engineering Circular No. 11, Publication FHWA-IP-89-016, 156 p.

Federal Highway Administration, 1983, Runoff estimates for small watersheds and development of sound design: Federal Highway Administration Report FHWA-RD-77-158

Froehlich, D.C., 1989, Local scour at bridge abutments in Ports, M.A., ed., Hydraulic Engineering--Proceedings of the 1989 National Conference on Hydraulic Engineering: New York, American Society of Civil Engineers, p. 13-18.

Hayes, D.C.,1993, Site selection and collection of bridge-scour data in Delaware, Maryland, and Virginia: U.S. Geological Survey WaterResources Investigation Report 93-4017, 23 p.

Johnson, C.G. and Tasker, G.D.,1974, Progress report on flood magnitude and frequency of Vermont streams: U.S. Geological Survey OpenFile Report 74-130, 37 p.

Lagasse, P.F., Schall, J.D., Johnson, F., Richardson, E.V., Chang, F., 1995, Stream Stability at Highway Structures: Federal Highway Administration Hydraulic Engineering Circular No. 20, Publication FHWA-IP-90-014, 144 p.

Laursen, E.M., 1960, Scour at bridge crossings: Journal of the Hydraulics Division, American Society of Civil Engineers, v. 86, no. HY2, p. 39-53.

Potter, W. D., 1957a, Peak rates of runoff in the Adirondack, White Mountains, and Maine woods area, Bureau of Public Roads

Potter, W. D., 1957b, Peak rates of runoff in the New England Hill and Lowland area, Bureau of Public Roads

Richardson, E.V. and Davis, S.R., 1995, Evaluating scour at bridges: Federal Highway Administration Hydraulic Engineering Circular No. 18, Publication FHWA-IP-90-017, 204 p.

Richardson, E.V., Simons, D.B., and Julien, P.Y., 1990, Highways in the river environment: Federal Highway Administration Publication FHWA-HI-90-016.

Ritter, D.F., 1984, Process Geomorphology: W.C. Brown Co., Debuque, Iowa, 603 p.

Shearman, J.O., 1990, User's manual for WSPRO--a computer model for water surface profile computations: Federal Highway Administration Publication FHWA-IP-89-027, 187 p.

Shearman, J.O., Kirby, W.H., Schneider, V.R., and Flippo, H.N., 1986, Bridge waterways analysis model; research report: Federal Highway Administration Publication FHWA-RD-86-108, 112 p.

Talbot, A.N., 1887, The determination of water-way for bridges and culverts.

U.S. Department of Transportation, 1993, Stream stability and scour at highway bridges, Participant Workbook: Federal Highway Administration Publication FHWA HI-91-011.

U.S. Geological Survey, 1944, East Middlebury, Vermont 7.5 Minute Series quadrangle map: U.S. Geological Survey Topographic Maps; Photorevised, 1972; Photoinspected 1983; Contour interval, 20 feet; Scale 1:24,000.

U.S. Geological Survey, 1943, Cornwall, Vermont 7.5 Minute Series quadrangle map: U.S. Geological Survey Topographic Maps; Photoinspected, 1983; Contour interval, 20 feet; Scale 1:24,000. 


\section{APPENDIX A: \\ WSPRO INPUT FILE}




\section{WSPRO INPUT FILE}

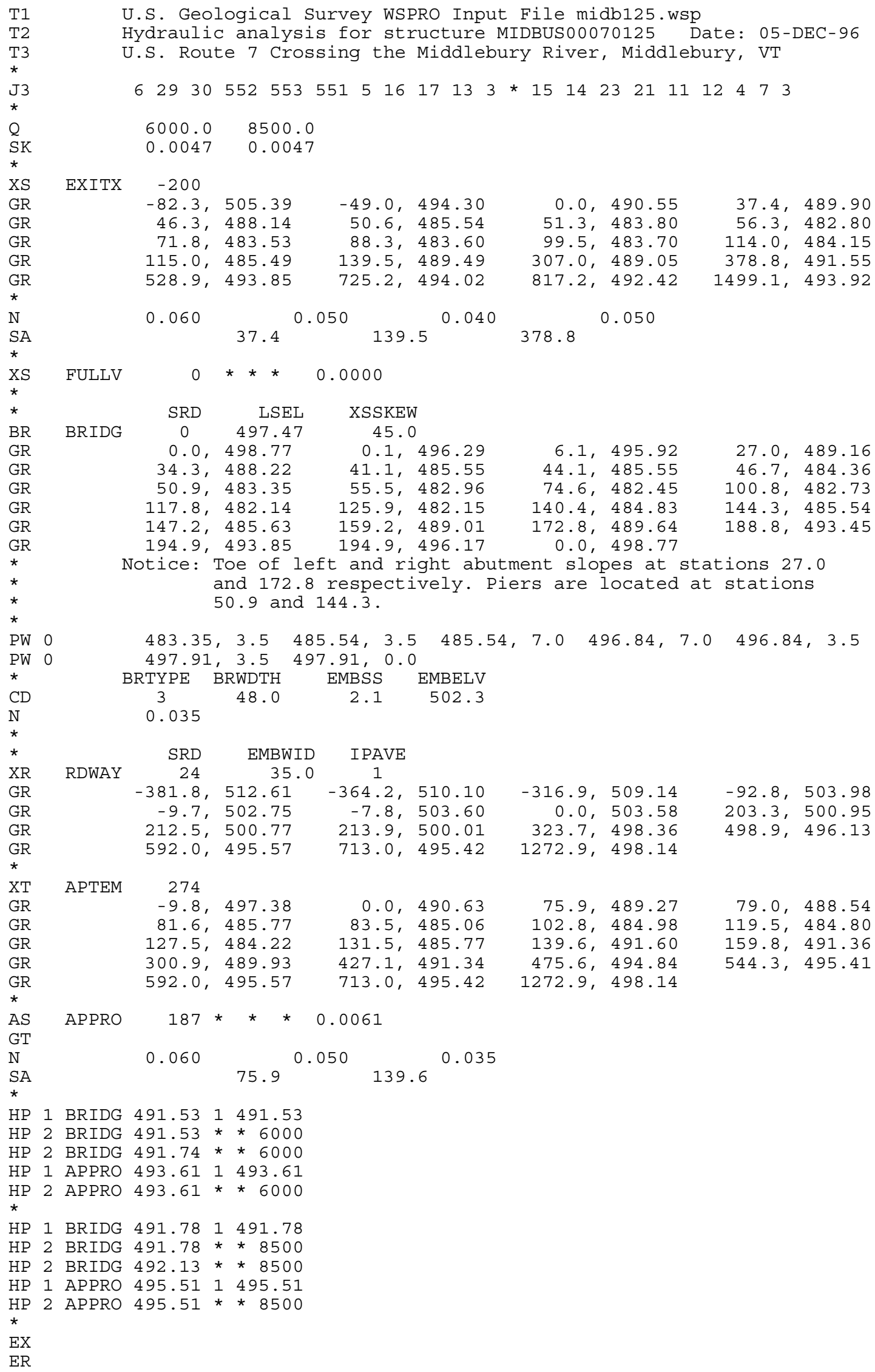




\section{APPENDIX B: \\ WSPRO OUTPUT FILE}




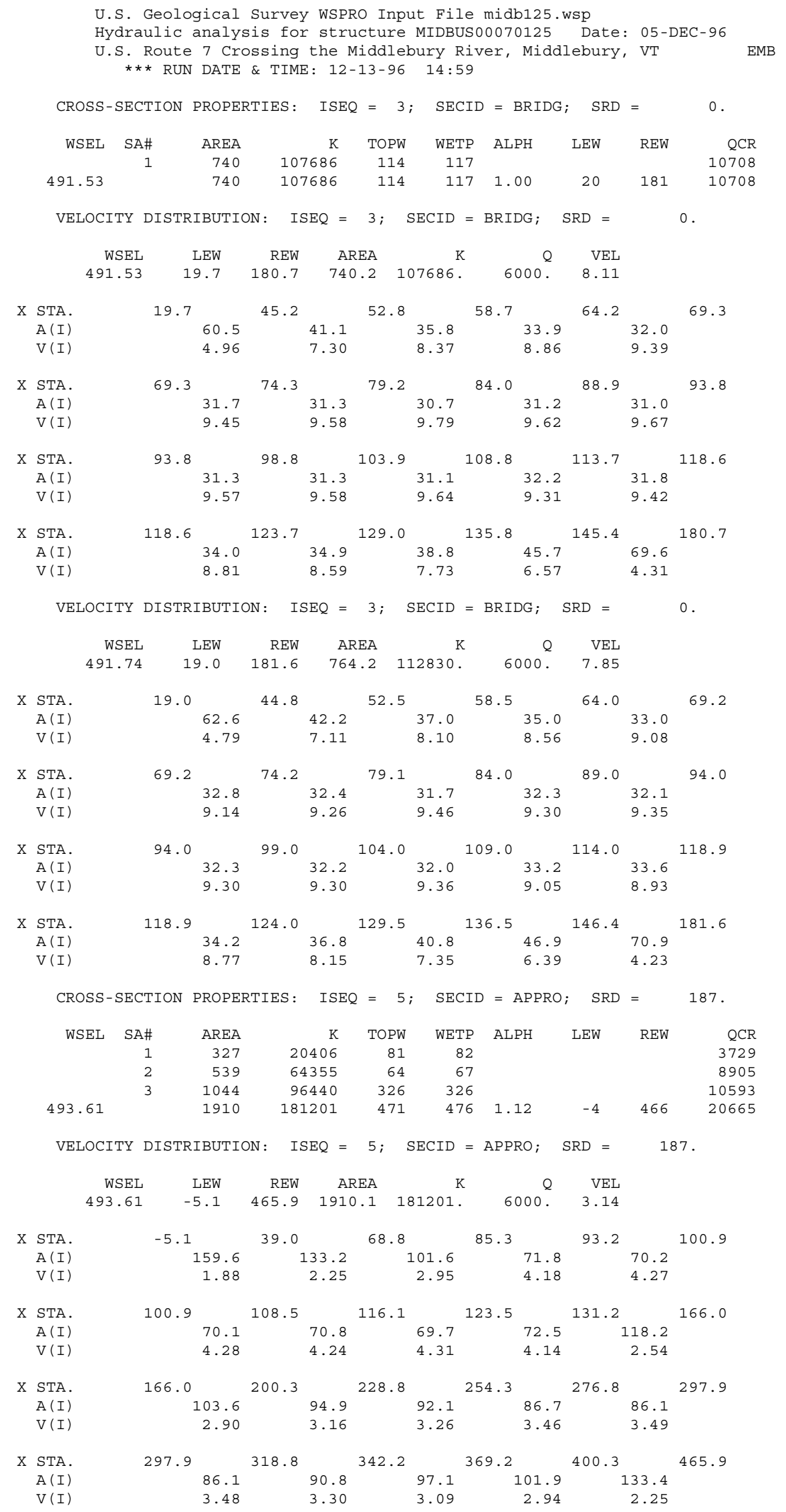


WSPRO OUTPUT FILE (continued)

\author{
U.S. Geological Survey WSPRO Input File midb125.wsp \\ Hydraulic analysis for structure MIDBUS00070125 Date: 05-DEC-96 \\ U.S. Route 7 Crossing the Middlebury River, Middlebury, VT EMB \\ *** RUN DATE \& TIME: 12-13-96 14:59 \\ CROSS-SECTION PROPERTIES: ISEQ $=3 ;$ SECID $=$ BRIDG $; \quad$ SRD $=0$. \\ $\begin{array}{rrrrrrrr}\text { WSEL SA\# } & \text { AREA } & \mathrm{K} & \text { TOPW } & \text { WETP } & \text { ALPH } & \text { LEW } & \text { REW }\end{array}$

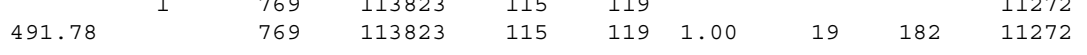 \\ VELOCITY DISTRIBUTION: ISEQ $=3 ;$ SECID $=$ BRIDG; $\operatorname{SRD}=0$.

$\begin{array}{rrrrrrr}\text { WSEL } & \text { LEW } & \text { REW } & \text { AREA } & \text { K } & \text { Q } & \text { VEL } \\ 491.78 & 18.9 & 181.8 & 768.8 & 113823 . & 8500 . & 11.06\end{array}$

\begin{tabular}{|c|c|c|c|c|c|c|c|}
\hline \multirow[t]{3}{*}{$\mathrm{X}$} & STA. & 18.9 & 44.7 & 52.4 & 58.6 & 64.0 & 69.2 \\
\hline & $A(I)$ & 62.9 & 42.4 & 38.3 & 34.2 & 34.0 & \\
\hline & $V(I)$ & 6.75 & 10.02 & 11.10 & 12.42 & 12.50 & \\
\hline \multirow[t]{3}{*}{$\mathrm{X}$} & STA. & 69.2 & 74.3 & 79.2 & 84.0 & 89.0 & 94.0 \\
\hline & $A(I)$ & 32.9 & 32.4 & 31.7 & 32.3 & 32.1 & \\
\hline & $V(I)$ & 12.93 & 13.11 & 13.39 & 13.15 & 13.23 & \\
\hline \multirow[t]{3}{*}{$\mathrm{x}$} & STA. & 94.0 & 99.0 & 104.1 & 109.1 & 114.0 & 119.0 \\
\hline & $A(I)$ & 32.1 & 33.1 & 32.4 & 32.9 & 33.8 & \\
\hline & $V(I)$ & 13.23 & 12.83 & 13.11 & 12.93 & 12.57 & \\
\hline \multirow[t]{3}{*}{$\mathrm{x}$} & STA. & 119.0 & 124.1 & 129.6 & 136.6 & 146.5 & 181.8 \\
\hline & $A(I)$ & 34.4 & 37.0 & 41.0 & 47.2 & 71.5 & \\
\hline & $V(I)$ & 12.35 & 11.48 & 10.36 & 9.01 & 5.95 & \\
\hline
\end{tabular} \\ VELOCITY DISTRIBUTION: ISEQ $=3 ;$ SECID $=$ BRIDG $; \quad$ SRD $=0$.

\begin{tabular}{|c|c|c|c|c|c|c|c|c|c|c|c|}
\hline & & SEL & LEW & REW & $A R I$ & $E A$ & $\mathrm{~K}$ & $Q$ & VEL & & \\
\hline & 492 & .13 & 17.8 & 183.3 & 809 & .5 & 690. & 8500 . & 10.50 & & \\
\hline $\mathrm{x}$ & STA. & 17.8 & & 44.1 & & 52.1 & & 8.2 & 63.8 & & 69.0 \\
\hline & $A(I)$ & & 66.4 & & 45.3 & & 9.1 & 37.0 & & 34.9 & \\
\hline & $V(I)$ & & 6.40 & & 9.37 & & .86 & 11.47 & & 2.17 & \\
\hline $\mathrm{X}$ & STA. & 69.0 & & 74.1 & & 79.1 & & 4.1 & 89.1 & & 94.2 \\
\hline & $A(I)$ & & 34.7 & & 34.2 & & 3.5 & 34.1 & & 33.9 & \\
\hline & $\mathrm{V}(\mathrm{I})$ & & 12.26 & & 12.42 & & .69 & 12.46 & & 2.53 & \\
\hline $\mathrm{X}$ & STA. & 94.2 & & 99.3 & & 104.4 & & 9.4 & 114.4 & & 119.5 \\
\hline & $A(I)$ & & 34.3 & & 34.3 & & 4.1 & 34.5 & & 35.5 & \\
\hline & $V(I)$ & & 12.40 & & 12.39 & & .47 & 12.31 & & 1.98 & \\
\hline $\mathrm{X}$ & STA. & 119.5 & & 124.6 & & 130.4 & 13 & 7.5 & 147.8 & & 183.3 \\
\hline & $A(I)$ & & 36.1 & & 39.6 & & 2.7 & 50.6 & & 74.5 & \\
\hline & $V(I)$ & & 11.78 & & 10.72 & & .95 & 8.39 & & 5.71 & \\
\hline & CROSS - & SECTION & PROPER & RTIES: & ISEQ & $5 ;$ & SECID & $=\mathrm{APPRO} ;$ & SRD & $=$ & 187. \\
\hline & WSEL & SA\# & AREA & & K & TOPW & WETP & $\mathrm{ALPH}$ & LEW & REW & QCR \\
\hline & & 1 & 484 & & 8130 & 84 & 85 & & & & 6593 \\
\hline & & 2 & 660 & & 0185 & 64 & 67 & & & & 12064 \\
\hline & & 3 & 1874 & 15 & 3574 & 701 & 701 & & & & 17380 \\
\hline & 495.51 & & 3018 & 28 & 1889 & 849 & 854 & 1.20 & -7 & 841 & 29480 \\
\hline
\end{tabular} \\ VELOCITY DISTRIBUTION : ISEQ $=5 ; \quad$ SECID $=$ APPRO $; \quad$ SRD $=187$.

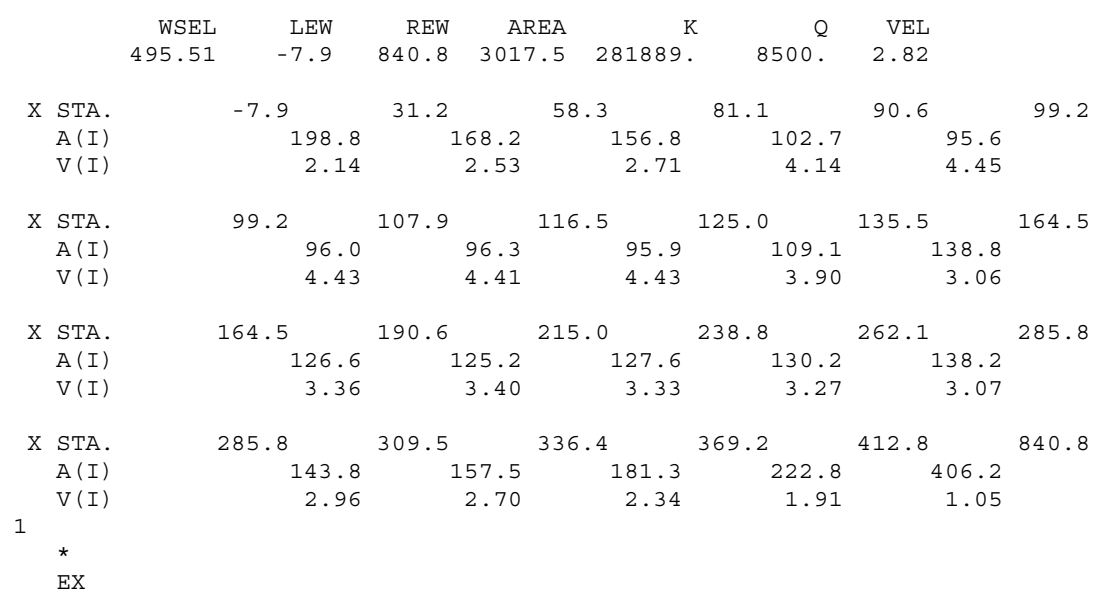


WSPRO OUTPUT FILE (continued)

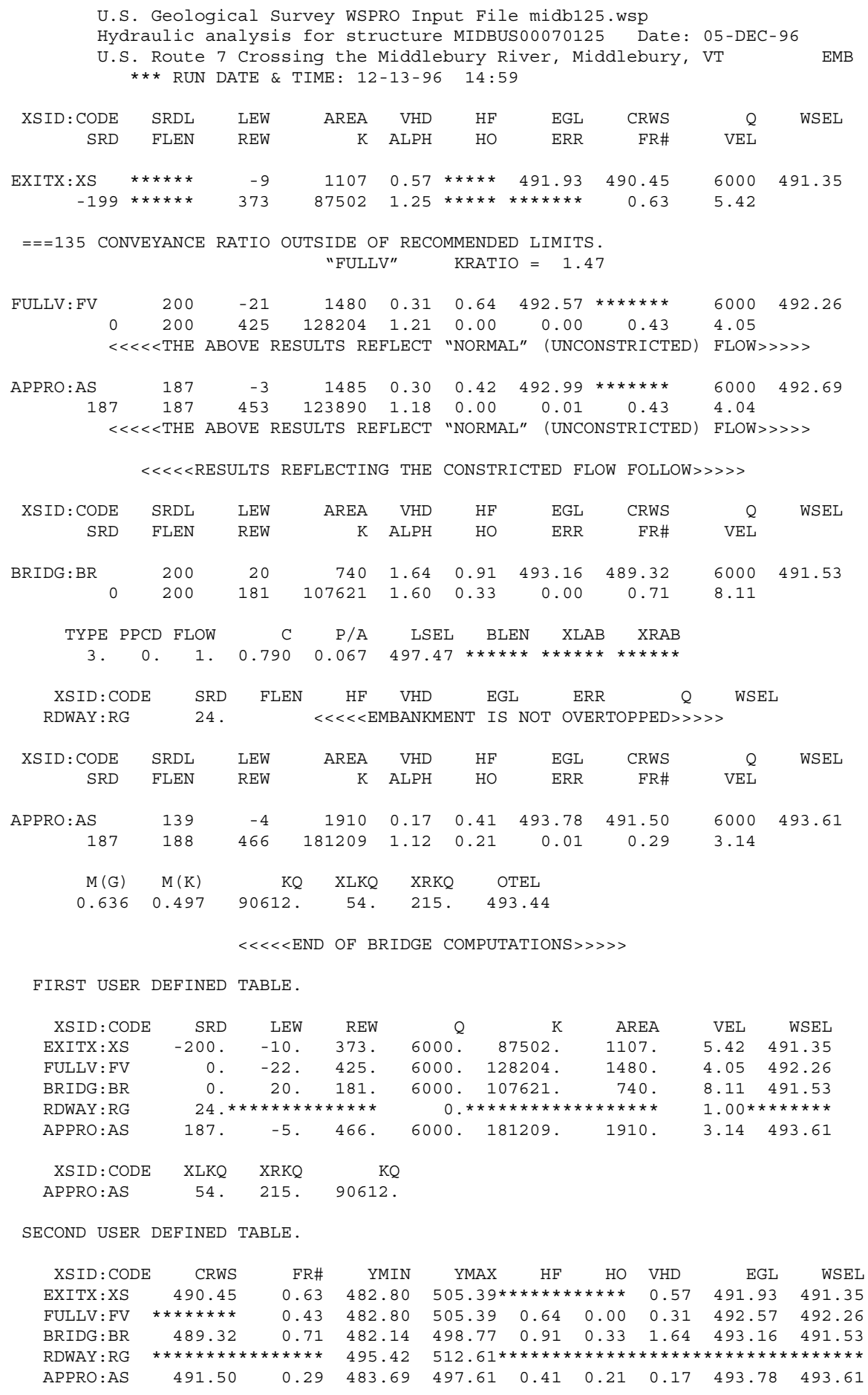


WSPRO OUTPUT FILE (continued)

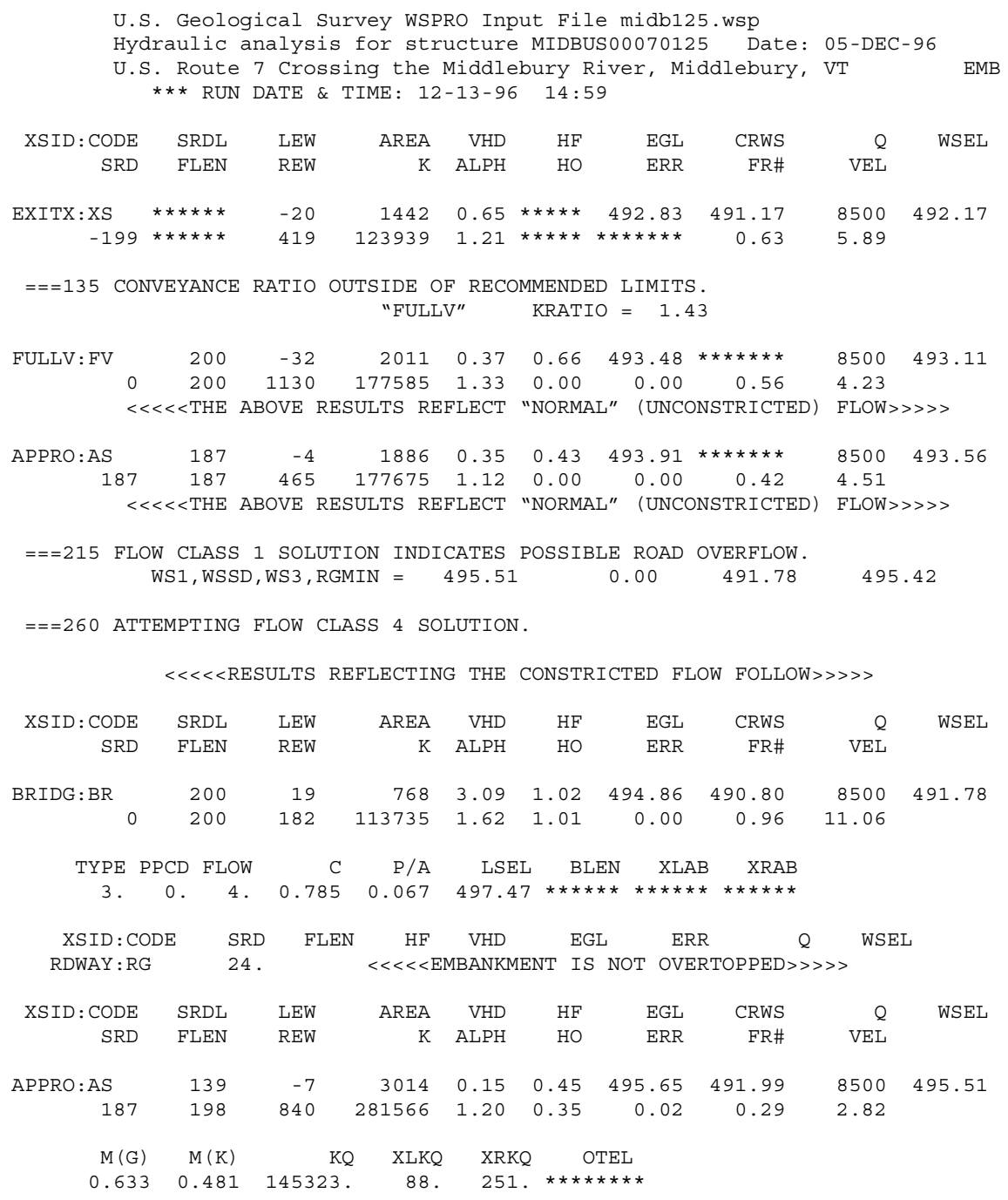

$<<<<<$ END OF BRIDGE COMPUTATIONS $>>>>>$

FIRST USER DEFINED TABLE.

\begin{tabular}{|c|c|c|c|c|c|c|c|c|}
\hline XSID : CODE & SRD & LEW & REW & 0 & $\mathrm{~K}$ & AREA & VEL & WSEL \\
\hline EXITX:XS & -200. & -21 & 419. & 8500 . & 123939. & 1442 . & 5.89 & 492.17 \\
\hline FULLV : FV & 0. & -33. & 1130. & 8500. & 177585. & 2011. & 4.23 & 493.11 \\
\hline BRIDG : BR & 0 . & 19. & 182. & 8500 . & 113735. & 768 & 11.06 & 491.78 \\
\hline RDWAY : RG & 24 & 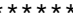 & 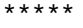 & 0 . & 0 . & 0 . & \multicolumn{2}{|c|}{$1.00 * * * * * * * *$} \\
\hline APPRO: AS & 187. & -8 & 840 & 8500. & 281566 . & 3014 . & 2.82 & 495.51 \\
\hline XSID : CODE & XLKQ & XRKQ & & & & & & \\
\hline APPRO : AS & 88. & 251. & 145323 & & & & & \\
\hline
\end{tabular}

SECOND USER DEFINED TABLE.

$\begin{array}{lccrccccrr}\text { XSID:CODE } & \text { CRWS } & \text { FR\# } & \text { YMIN } & \text { YMAX } & \text { HF } & \text { HO } & \text { VHD } & \text { EGL } & \text { WSEL } \\ \text { EXITX:XS } & 491.17 & 0.63 & 482.80 & 505.39 * * * * * * * * * * * & 0.65 & 492.83 & 492.17 \\ \text { FULLV:FV } & * * * * * * * & 0.56 & 482.80 & 505.39 & 0.66 & 0.00 & 0.37 & 493.48 & 493.11 \\ \text { BRIDG:BR } & 490.80 & 0.96 & 482.14 & 498.77 & 1.02 & 1.01 & 3.09 & 494.86 & 491.78 \\ \text { RDWAY:RG } & * * * * * * * * * * * * * * & 495.42 & 512.61 & 0.14 * * * * * & 0.15 & 495.50 * * * * * * \\ \text { APPRO:AS } & 491.99 & 0.29 & 483.69 & 497.61 & 0.45 & 0.35 & 0.15 & 495.65 & 495.51 \\ \text { ER } & & & & & & & & & \end{array}$




\section{APPENDIX C:}

\section{BED-MATERIAL PARTICAL-SIZE DISTRIBUTION}




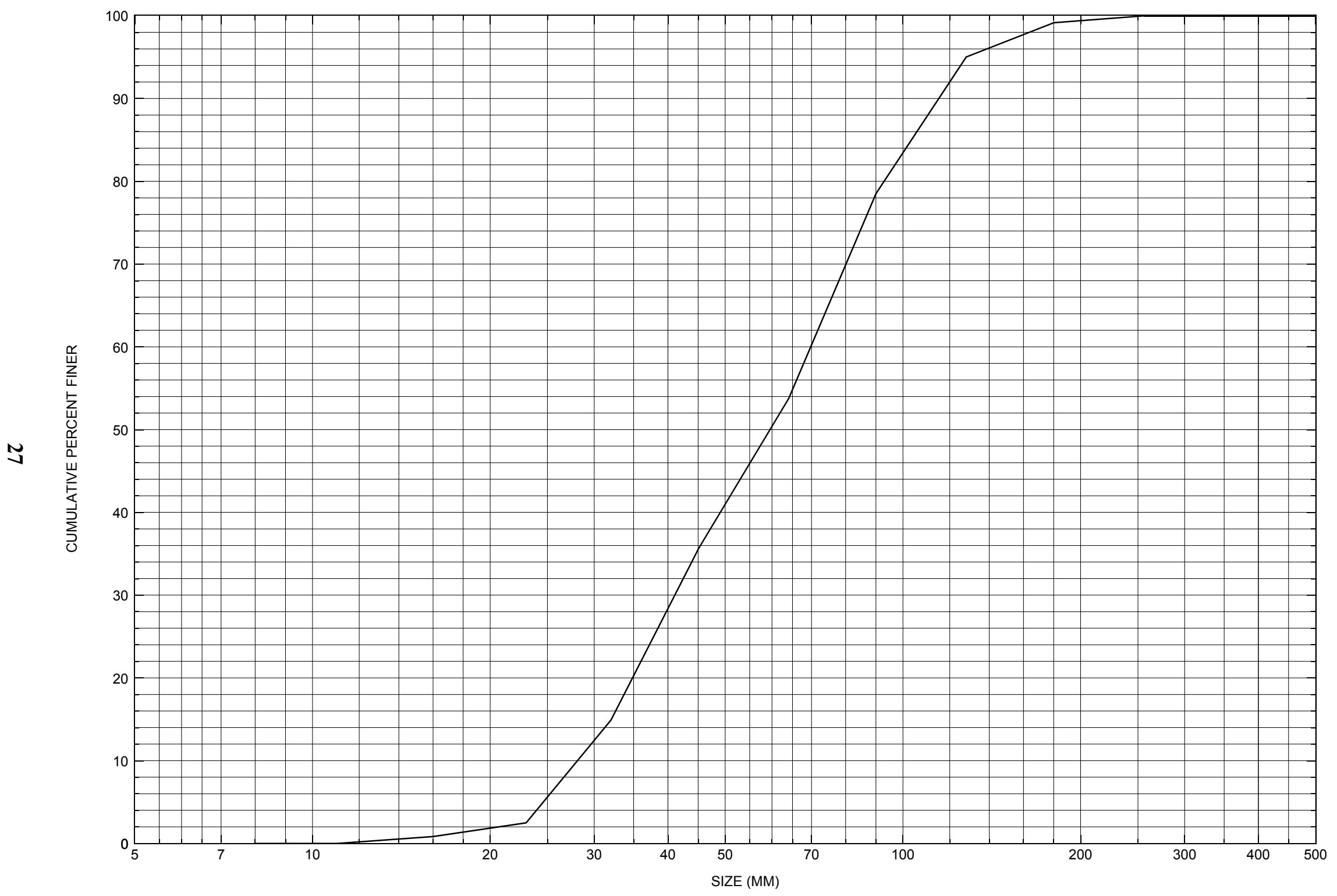

Appendix C. Bed material particle-size distribution for a pebble count transect at the channel approach of structure MIDBUS00070125, in Middlebury, Vermont. 


\section{APPENDIX D: \\ HISTORICAL DATA FORM}




\section{Structure Number MIDBUS00070125}

\section{General Location Descriptive}

Data collected by (First Initial, Full last name) $\underline{\mathbf{L}}$. Medalie

Date $(M M / D D / Y Y)+12 / 14 / \underline{95}$

Highway District Number (I - 2; nn) $\mathbf{0 5}$

Town (FIPS place code; I - 4; nnnnn) $\mathbf{4 4 3 5 0}$

Waterway (I - 6) MIDDLEBURY RIVER

Route Number US7 ML

Topographic Map East.Middlebury

Latitude (I - 16; nnnn.n) $\mathbf{4 3 5 8 0}$
County (FIPS county code; I - 3; nnn)

Mile marker (I - 11; nnn.nnn) $\mathbf{0 0 0 6 5 0}$

Road Name (I - 7): -

Vicinity (I - 9) 0.3 MI S JCT. VT.116

Hydrologic Unit Code: 2010002

Longitude (i - 17; nnnnn.n) 73069

\section{Select Federal Inventory Codes}

FHWA Structure Number (I - 8) 20001901250111

Maintenance responsibility $(I-21 ; n n) \quad 01$

Year built (I - 27; YYYY) 1964

Average daily traffic, ADT (I - 29; nnnnnn) 007639

Year of ADT (I - 30; YY) $\mathbf{9 2}$

Opening skew to Roadway $(I-34 ; n n) \quad 45$

Operational status $(I-41 ; X) \underline{\mathbf{A}}$

Structure type (I- 43; nnn) $\mathbf{3 0 2}$

Approach span structure type (I - 44; nnn) $\mathbf{0 0 0}$

Number of spans (I - 45; nnn) $\underline{\mathbf{0 0 3}}$

Number of approach spans (I - 46; nnnn) $\mathbf{0 0 0 0}$

Comments:

According to the structural inspection report dated 9/29/93, structure is a 3-span steel beam bridge. The curtain wall, bridge seat, stem and wings at the right abutment are in good condition except for some minor shrinkage cracking. Both abutments are protected with stone fill. The channel is straight through the structure. Flow is mostly through the middle span, where there is also a silt and sand buildup. There is some minor scour at the upstream end of the right pier; however, the footing is not exposed. There are cracks, scaling, and cracks in the tie walls of the columns of the piers. 


\section{Bridge Hydrologic Data}

Is there hydrologic data available? $\underline{\mathbf{Y}}$ if No, type ctrl- $n$ h VTAOT Drainage area $\left(m i^{2}\right): \underline{\mathbf{4 7 . 1 2}}$

Terrain character: Hilly to mountainous

Stream character \& type: -

Streambed material:

Discharge Data (cfs):

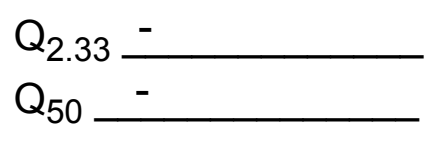

Record flood date $(M M / D D / Y Y):-{ }^{\prime}-$
Estimated Discharge $(c f s):-$

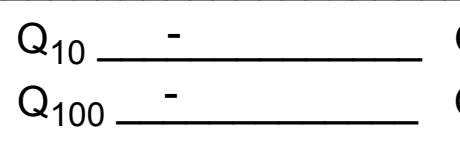

$Q_{25}-$

Water surface elevation $(f t)$ : $(\mathrm{ft} / \mathrm{s}):$

Ice conditions (Heavy, Moderate, Light): Moderate Debris (Heavy, Moderate, Light): Moderate

The stage increases to maximum highwater elevation (Rapidly, Not rapidly): Rapidly

The stream response is (Flashy, Not flashy):

Describe any significant site conditions upstream or downstream that may influence the stream's stage: -

Watershed storage area (in percent):

The watershed storage area is: - (1-mainly at the headwaters; 2- uniformly distributed; 3-immediatly upstream oi the site)

Water Surface Elevation Estimates for Existing Structure:

\begin{tabular}{|l|l|l|l|l|l|}
\hline Peak discharge frequency & $Q_{2.33}$ & $Q_{10}$ & $Q_{25}$ & $Q_{50}$ & $Q_{100}$ \\
Water surface elevation (ft)) & - & - & - & - & - \\
Velocity (ft/sec) & - & - & - & - & - \\
\hline
\end{tabular}

Long term stream bed changes: -

Is the roadway overtopped below the $\mathrm{Q}_{100}$ ? (Yes, No, Unknown): $\mathbf{U} \quad$ Frequency: -

Relief Elevation $(f t)$ :

Discharge over roadway at $Q_{100}\left(f^{3} / \mathrm{sec}\right)$ :

Are there other structures nearby? (Yes, No, Unknown): $\mathbf{U}$ Upstream distance (miles): Town: If No or Unknown, type ctrl-n os Highway No. : Structure No. : Year Built:

Clear span (ft): Clear Height (ft): Full Waterway $\left(f t^{2}\right)$ : 
Downstream distance (miles): Town: Year Built:

Highway No. : Structure No. : Structure Type:

Clear span $(f t):$ Clear Height $(f t)$ : Full Waterway $\left(f^{2}\right)$ :

Comments:

Hydraulic information on sheet 12 of plans includes ordinary high water elev. $=371.3$ feet, extreme highwater elev. $=376.6$ feet, low water elev. $=368.3$ feet, velocity at high water stage $=9.8 \mathrm{fps}$ with an estimated $\mathbf{Q}=\mathbf{5 4 0 0} \mathrm{cfs}$ and a moderate to heavy scour potential.

\section{USGS Watershed Data}

Watershed Hydrographic Data

Drainage area $(D A) \stackrel{46.778}{\mathrm{mi}^{2}}$

Watershed storage (ST) $\quad \mathbf{0 . 4 2}$

Bridge site elevation $\mathbf{3 7 0} \mathrm{ft}$ $\%$

Main channel length 12.12 $\mathrm{mi}$

$10 \%$ channel length elevation $\quad \mathbf{4 4 0}$

Lake and pond area $\mathbf{0 . 1 9 6}$ $\mathrm{mi}^{2}$

Main channel slope

(S) 140.81 $\mathrm{ft} / \mathrm{mi}$

Watershed Precipitation Data

Average site precipitation in Average headwater precipitation in

Maximum 2yr-24hr precipitation event $(124,2)$ in

Average seasonal snowfall (Sn) $\mathrm{ft}$ 


\section{Bridge Plan Data}

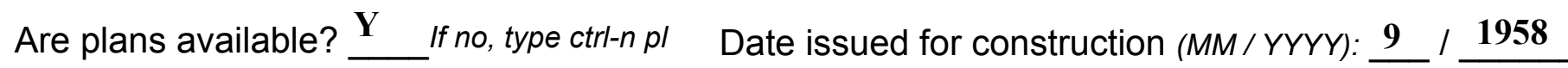
Project Number F019-3(10) Minimum channel bed elevation:

Low superstructure elevation: USLAB $\underline{\mathbf{3 8 1 . 3 1}}$ DSLAB $\underline{\mathbf{3 8 1 . 7 1}}$ USRAB $\underline{\mathbf{3 7 8 . 6 9}}$ DSRAB $\underline{\text { 379.08 }}$ Benchmark location description:

BM \#23, chiseled square on right abutment (US end?) of old structure, elev. 376.12 feet.

Reference Point (MSL, Arbitrary, Other): Arbitrary $\quad$ Datum (NAD27, NAD83, Other): -

Foundation Type: $\mathbf{2}$ (1-Spreadfooting; 2-Pile; 3- Gravity; 4-Unknown)

If 1: Footing Thickness ___ Footing bottom elevation:

If 2: Pile Type: $\underline{\mathbf{2}}$ (1-Wood; 2-Steel or metal; 3-Concrete) Approximate pile driven length: $\underline{\mathbf{1 8 - 2 5}}$

If 3: Footing bottom elevation:

Is boring information available? $\underline{\mathbf{Y}}$ If no, type ctrl- $n$ bi Number of borings taken: $\underline{\mathbf{8}}$

Foundation Material Type: 1 (1-regolith, 2-bedrock, 3-unknown)

Briefly describe material at foundation bottom elevation or around piles:

Average steel pile length at the left abutment is 18' and at the right abutment is 25 feet. Material around the top quarter of the piles at the Labut is loose sand; beneath that the material becomes very compact. Around the piles at the right abutment, material is hard and coarse sand, gravel, and some clay.

Comments:

The bottom of the concrete footing of the left and right abutment are at elevations 374.6 and 372.1 feet respectively. The bottom of footing at the left pier (pier 1 ) is $\mathbf{3 6 0 . 2}$ feet and the right pier (pier 2) is 357.18 feet. The low superstructure elevations are bridge seat elevations from the bridge plans. 


\section{Cross-sectional Data}

Is cross-sectional data available? $\mathbf{N}$ If no, type ctrl-n xs

Source (FEMA, VTAOT, Other)? -

Comments: NO CROSS SECTIONAL INFORMATION

\begin{tabular}{|l|l|l|l|l|l|l|l|l|l|l|l|}
\hline Station & & - & - & - & - & - & - & - & - & - & - \\
\hline Feature & - & - & - & - & - & - & - & - & - & - & - \\
\hline $\begin{array}{l}\text { Low cord } \\
\text { elevation }\end{array}$ & - & - & - & - & - & - & - & - & - & - & - \\
\hline $\begin{array}{l}\text { Bed } \\
\text { elevation }\end{array}$ & - & - & - & - & - & - & - & - & - & - & - \\
\hline $\begin{array}{l}\text { Low cord to } \\
\text { bed length }\end{array}$ & - & - & - & - & - & - & - & - & - & - & - \\
\hline Station & - & - & - & - & - & - & - & - & - & - & - \\
\hline Feature & - & - & - & - & - & - & - & - & - & - & - \\
\hline $\begin{array}{l}\text { Low cord } \\
\text { elevation }\end{array}$ & - & - & - & - & - & - & - & - & - & - & - \\
\hline $\begin{array}{l}\text { Bed } \\
\text { elevation }\end{array}$ & - & - & - & - & - & - & - & - & - & - & - \\
\hline $\begin{array}{l}\text { Low cord to } \\
\text { bed length }\end{array}$ & - & - & - & - & - & - & - & - & - & - & - \\
\hline
\end{tabular}

Source (FEMA, VTAOT, Other)?

Comments: -

\begin{tabular}{|l|l|l|l|l|l|l|l|l|l|l|l|}
\hline Station & & - & - & - & - & - & - & - & - & - & - \\
\hline Feature & - & - & - & - & - & - & - & - & - & - & - \\
\hline $\begin{array}{l}\text { Low cord } \\
\text { elevation }\end{array}$ & - & - & - & - & - & - & - & - & - & - & - \\
\hline $\begin{array}{l}\text { Bed } \\
\text { elevation }\end{array}$ & - & - & - & - & - & - & - & - & - & - & - \\
\hline $\begin{array}{l}\text { Low cord to } \\
\text { bed length }\end{array}$ & - & - & - & - & - & - & - & - & - & - & - \\
\hline Station & - & - & - & - & - & - & - & - & - & - & - \\
\hline Feature & - & - & - & - & - & - & - & - & - & - & - \\
\hline $\begin{array}{l}\text { Low cord } \\
\text { elevation }\end{array}$ & - & - & - & - & - & - & - & - & - & - & - \\
\hline $\begin{array}{l}\text { Bed } \\
\text { elevation }\end{array}$ & - & - & - & - & - & - & - & - & - & - & - \\
\hline $\begin{array}{l}\text { Low cord to } \\
\text { bed length }\end{array}$ & - & - & - & - & - & - & - & - & - & - & - \\
\hline
\end{tabular}




\section{APPENDIX E: \\ LEVEL I DATA FORM}


U. S. Geological Survey

Bridge Field Data Collection and Processing Form

Qa/Qc Check by: $\mathbf{R B}$ Date: $11 / 1 / 96$

\section{Structure Number}

\section{A. General Location Descriptive}

1. Data collected by (First Initial, Full last name) R. FLYNN

2. Highway District Number $\mathbf{0 5}$

Date $(M M / D D / Y Y) 06 / 18 / 1996$

County Addison (001)

Waterway (I - 6) MIDDLEBURY RIVER

Route Number US 7

Mile marker 00650

Town Middlebury (44350)

Road Name -

Hydrologic Unit Code: $\mathbf{0 2 0 1 0 0 0 2}$

3. Descriptive comments:

Located 0.3 miles south of the junction of VT 116 with U.S. 7.

\section{B. Bridge Deck Observations}
4. Surface cover... LBUS 6
RBUS 3
LBDS 6
RBDS 3
Overall 3

(2b us,ds,lb,rb: 1- Urban; 2- Suburban; 3- Row crops; 4- Pasture; 5- Shrub- and brushland; 6- Forest; 7- Wetland)
5. Ambient water surface... US 1
UB 1
DS 1
(1- pool; 2- riffle)

6. Bridge structure type 2 (1- single span; 2- multiple span; 3- single arch; 4- multiple arch; 5-cylindrical culvert; 6- box culvert; or 7- other)
7. Bridge length $\underline{\mathbf{2 0 2}}$
(feet)
Span length $\mathbf{9 1}$
(feet)
Bridge width 35 (feet)

\section{Road approach to bridge:}
8. LB $\underline{2}$ RB $\underline{1}$
( 0 even, 1- lower, 2- higher)
9. LB 1
RB 1
(1- Paved, 2- Not paved)

10. Embankment slope (run / rise in feet / foot)

$$
\text { US left }
$$

2.3:1

US right

1.9:1

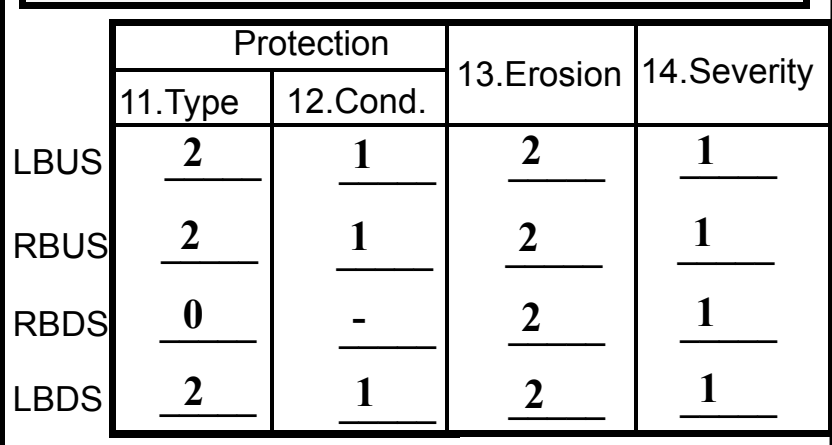

Bank protection types: 0- none; 1- $<12$ inches;

2- < 36 inches; 3- < 48 inches;

4- < 60 inches; 5- wall / artificial levee

Bank protection conditions: 1- good; 2- slumped;

3- eroded; 4- failed

Erosion: 0 - none; 1- channel erosion; 2 -

road wash; 3- both; 4- other

Erosion Severity: 0 - none; 1- slight; 2- moderate; 3- severe

\section{Channel approach to bridge (BF):}

15. Angle of approach: $1 \mathbf{1 0}$

16. Bridge skew: 45

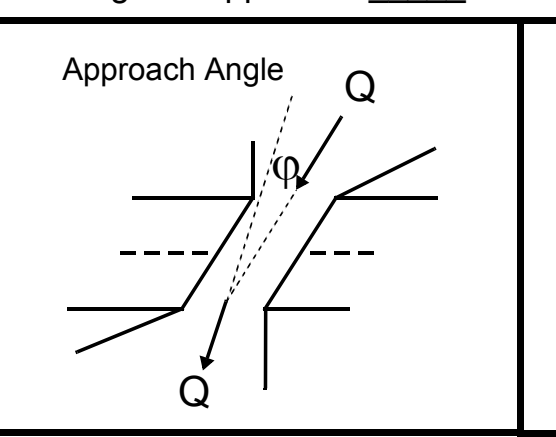

17. Channel impact zone 1:

Where? RB (LB, RB)

\section{Exist? $\underline{\mathbf{Y}}(\mathrm{Y}$ or $N)$}

Range? 80 feet US (US,

Channel impact zone 2:

Where? $(L B, R B)$

Range? - $\quad$ feet (US, UB, DS) to feet -

Impact Severity: 0- none to very slight; 1-Slight; 2- Moderate; 3- Severe 
18. Bridge Type: $\mathbf{3}$

1a- Vertical abutments with wingwalls

1 b- Vertical abutments without wingwalls

2- Vertical abutments and wingwalls, sloping embankment Wingwalls perpendicular to abut. face

3- Spill through abutments

4- Sloping embankment, vertical wingwalls and abutments

Wingwall angle less than $90^{\circ}$.

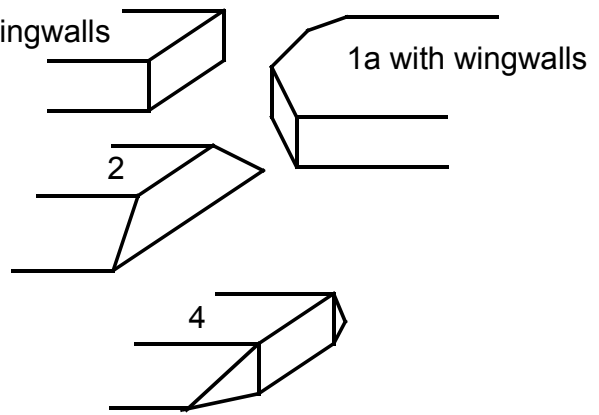

19. Bridge Deck Comments (surface cover variations, measured bridge and span lengths, bridge type variations, approach overflow width, etc.)

7. Measured bridge length is $203 \mathrm{ft}$. and the bridge width is $34.7 \mathrm{ft}$.

8. The right road approach has a slight slope for $200 \mathrm{ft}$. then it levels out.

11. The right bank protection US extends approximately $50 \mathrm{ft}$. US and $50 \mathrm{ft}$. along the road embankment.

18. There are piers on the left and right edges of the channel with sloping embankments behind them up to the abutments.

\section{Upstream Channel Assessment}

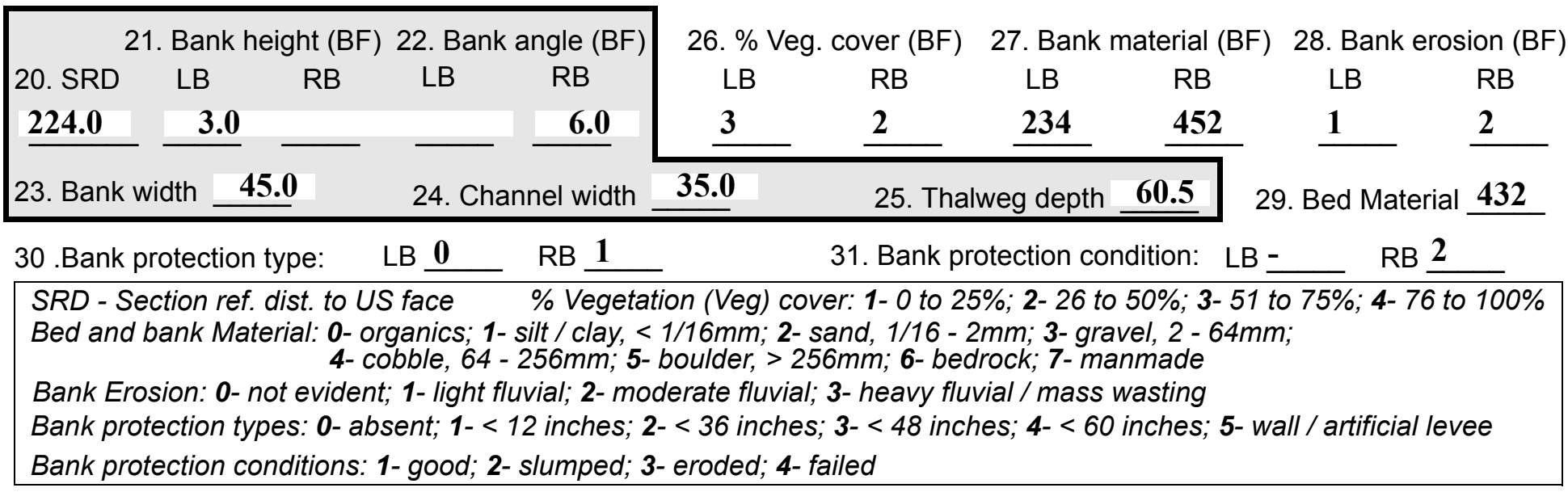

32. Comments (bank material variation, minor inflows, protection extent, etc.):

30. The right bank protection extends to $1000 \mathrm{ft}$. US and is generally in good condition with some slumping evident.

A riffle zone extends from $145 \mathrm{ft}$. US to $300 \mathrm{ft}$. US. The bed material is primarily cobble in the area of the riffle and becomes mostly sand from $60 \mathrm{ft}$. US to the bridge. 
36. Point bar extent: 0 feet US

(US, UB) to 200 feet $\underline{\mathbf{U S}}$

(US, UB, DS) positioned $\mathbf{0}$ $\%$ LB to $\mathbf{7 0}$ $\% \mathrm{RB}$

37. Material: 234

38. Point or side bar comments (Circle Point or Side; Note additional bars, material variation, status, etc.):

This point bar is submerged and blends into the cobble streambed about $200 \mathrm{ft}$. US. A tree approximately 10 ft. long and $20 \mathrm{ft}$. from the left edge of water is lodged on the point bar at $58 \mathrm{ft}$. US.

39. Is a cut-bank present? $\mathbf{Y}$ (Y or if $N$ type ctrl-n cb) 40. Where? $\underline{\mathbf{R B}}$ (LB or $R B)$

41. Mid-bank distance: 125 42. Cut bank extent: 165 feet $\underline{\mathbf{U S}}$ (US, UB) to $\underline{\mathbf{8 8}}$ feet $\underline{\mathbf{U S}}$ (US, UB, DS)

43. Bank damage: 1 (1- eroded and/or creep; 2- slip failure; 3- block failure)

44. Cut bank comments (eg. additional cut banks, protection condition, etc.):

There is slumping of cobble protection and tree root exposure is evident from $92 \mathrm{ft}$. to $98 \mathrm{ft}$. US.

45. Is channel scour present? $\mathbf{Y}$ (Y or if $N$ type ctrl-n cs)

47. Scour dimensions: Length $\mathbf{1 0}$ Width 8 Depth : 2

(1)

46. Mid-scour distance: 5 Position $\underline{\mathbf{0}} \%$ LB to $\underline{\mathbf{5 0}} \%$ RB

48. Scour comments (eg. additional scour areas, local scouring process, etc.):

Scour is at the US face of the right bridge pier.

\section{Are there major confluences? $\mathbf{N}$}

51. Confluence 1: Distance Confluence 2: Distance 52. Enters on Enters on 54. Confluence comments (eg. confluence name):

\section{NO MAJOR CONFLUENCES}

50. How many? -
53. Type- ( 1- perennial; 2- ephemeral)
Type - (1-perennial; 2- ephemeral) ( $(L B$ or $R B)$ (LB or $R B)$ (1-perennial; 2- ephemeral)

\section{Under Bridge Channel Assessment}

55. Channel restraint (BF)? LB 2

56. Height (BF)
LB RB
$\mathbf{5 0 . 0}-$
58. Bank width (BF) -
59. Channel width (Amb) 57 Angle (BF) LB RB 1.5 (1- natural bank; 2- abutment; 3- artificial levee)

Bed and bank Material: 0- organics; 1- silt / clay, < 1/16mm; 2- sand, 1/16 - 2mm; 3- gravel, 2 - 64mm; 4- cobble, 64 - 256mm; 5- boulder, > 256mm; 6- bedrock; 7- manmade

Bank Erosion: 0- not evident; 1- light fluvial; 2- moderate fluvial; 3- heavy fluvial / mass wasting

64. Comments (bank material variation, minor inflows, protection extent, etc.):

234

Piers are located at the left and right banks with river deposited sand behind them. The spill-through embankments are sand with type- 2 stone fill covering the sand. The right edge of water at the US right pier is $7 \mathrm{ft}$. to the right of the right side of the concrete pier. 
65. Debris and Ice Is there debris accumulation?

(Yor $N)$ 66. Where? $\underline{Y}$

67. Debris Potential 1 (1-Low; 2- Moderate; 3- High)

68. Capture Efficiency 2

(1- Upstream; 2- At bridge; 3- Both)

69. Is there evidence of ice build-up? 2

Ice Blockage Potential $\underline{\mathbf{N}}$

(1-Low; 2- Moderate; 3- High)

(1- Low; 2- Moderate; 3- High)

70. Debris and Ice Comments:

1

There are some fallen trees and branches on the left overbank upstream. However, the banks are stable and covered by "old growth" trees predominantly.

\begin{tabular}{|l|c|c|c|c|c|c|c|c|}
\hline Abutments & $\begin{array}{c}\text { 71. Attack } \\
\angle \text { (BF) }\end{array}$ & $\begin{array}{c}72 \text {. Slope } \angle \\
\text { (Qmax) }\end{array}$ & $\begin{array}{c}\text { 73. Toe } \\
\text { loc. (BF) }\end{array}$ & $\begin{array}{c}\text { 74. Scour } \\
\text { Condition }\end{array}$ & $\begin{array}{c}75 . \text { Scour } \\
\text { depth }\end{array}$ & $\begin{array}{c}\text { 76. Exposure } \\
\text { depth }\end{array}$ & 77. Material & 78. Length \\
\hline LABUT & & $\mathbf{5}$ & $\mathbf{3 0}$ & $\mathbf{0}$ & $\mathbf{0}$ & - & - & $\mathbf{9 0 . 0}$ \\
\hline RABUT & $\mathbf{1}$ & - & $\mathbf{1 0}$ & & & $\mathbf{0}$ & $\mathbf{0}$ & $\mathbf{1 3 8 . 5}$ \\
\hline
\end{tabular}

Pushed: $L B$ or RB

Toe Location (Loc.): 0- even, 1- set back, 2- protrudes

Scour cond.: 0- not evident; 1- evident (comment); 2- footing exposed; 3-undermined footing; 4- piling exposed; 5- settled; 6- failed

Materials: 1- Concrete; 2- Stone masonry or drywall; 3- steel or metal; 4- wood

79. Abutment comments (eg. undermined penetration, unusual scour processes, debris, etc.):

$-$

1

The spill-through embankments in front of the left and right abutment are sloping at angles of 30 and 10 degrees respectively.

80. Wingwalls:

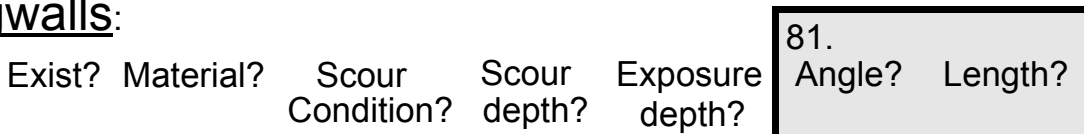

USLWW:

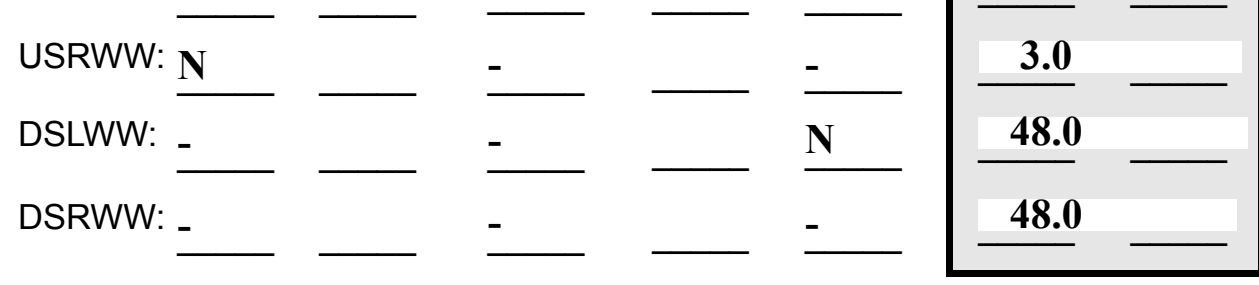

Wingwall materials: 1- Concrete; 2- Stone masonry or drywall; 3- steel or metal; 4- wood

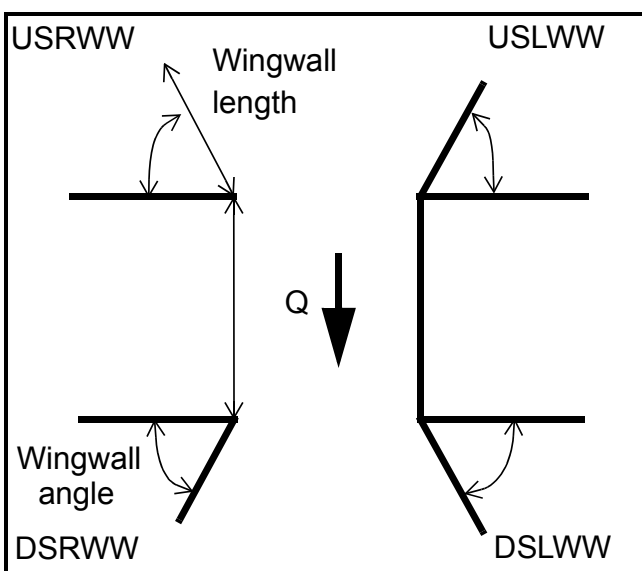

82. Bank / Bridge Protection:

\begin{tabular}{|l|l|l|l|l|l|l|l|c|}
\hline Location & USLWW & USRWW & LABUT & RABUT & LB & RB & DSLWW & DSRWW \\
\hline Type & - & - & N & - & - & - & $\mathbf{1}$ & $\mathbf{1}$ \\
\hline Condition & N & - & - & - & - & - & $\mathbf{1}$ & $\mathbf{1}$ \\
\hline Extent & - & - & - & - & - & $\mathbf{2}$ & $\mathbf{2}$ & - \\
\hline
\end{tabular}

Bank / Bridge protection types: 0- absent; 1- < 12 inches; 2- < 36 inches; 3- < 48 inches; 4- < 60 inches; 
83. Wingwall and protection comments (eg. undermined penetration, unusual scour processes, etc.):

-
-
-
-
-
-
-

\section{Piers:}

84. Are there piers? _ _ (Y or if $N$ type ctrl-n pr)

\begin{tabular}{|l|l|l|l|l|l|l|l|}
\hline \multirow{2}{*}{$\begin{array}{l}85 . \\
\text { Pier no. }\end{array}$} & \multicolumn{3}{|c|}{ width (w) feet } & \multicolumn{3}{c|}{ elevation (e) feet } \\
\cline { 2 - 9 } & w1 & w2 & w3 & e@w1 & e@w2 & e@w3 \\
\hline Pier 1 & - & - & - & - & - & - \\
\hline Pier 2 & - & $\mathbf{3 . 5}$ & $\mathbf{3 . 5}$ & - & $\mathbf{4 8 3 . 3 5}$ & $\mathbf{4 9 7 . 9 1}$ \\
\hline Pier 3 & - & $\mathbf{3 . 5}$ & $\mathbf{3 . 5}$ & - & $\mathbf{4 8 5 . 5 4}$ & $\mathbf{4 9 6 . 8 4}$ \\
\hline Pier 4 & - & - & - & - & - & - \\
Nyyyyy
\end{tabular}

\begin{tabular}{|l|l|l|l|l|}
\hline Level 1 Pier Descr. & \multicolumn{1}{|c|}{1} & \multicolumn{1}{|c|}{2} & \multicolumn{1}{|c|}{4} \\
\hline 86. Location (BF) & & $\mathbf{R}$ & MC & - \\
\hline 87. Type & & $\mathbf{1}$ & $\mathbf{L}$ & - \\
\hline 88. Material & & $\mathbf{2}$ & $\mathbf{1}$ & - \\
\hline 89. Shape & & $\mathbf{1}$ & $\mathbf{2}$ & - \\
\hline 90. Inclined? & & $\mathbf{N}$ & $\mathbf{1}$ & - \\
\hline 91. Attack $\angle$ (BF) & & $\mathbf{5}$ & $\mathbf{N}$ & - \\
\hline 92. Pushed & & $\mathbf{L B}$ & $\mathbf{0}$ & - \\
\hline 93. Length (feet) & - & - & - & - \\
\hline 94. \# of piles & & $\mathbf{1}$ & LB & - \\
\hline 95. Cross-members & & $\mathbf{0}$ & $\mathbf{1}$ & - \\
\hline 96. Scour Condition & & $\mathbf{1}$ & $\mathbf{0}$ & - \\
\hline 97. Scour depth & $\mathbf{Y}$ & $\mathbf{4}$ & $\mathbf{0}$ & - \\
\hline 98. Exposure depth & MC & $\mathbf{2}$ & - & - \\
\hline
\end{tabular}

LFP, LTB, LB, MCL, MCM, MCR, RB, RTB, RFP

1- Solid pier, 2- column, 3- bent

1-Wood; 2-concrete; 3- metal; 4- stone

1- Round; 2- Square; 3- Pointed

Y-yes; $N$ - no

$L B$ or $R B$

0- none; 1- laterals; 2- diagonals; 3- both

0- not evident; 1- evident (comment);

2- footing exposed; 3- piling exposed;

4- undermined footing; 5- settled; 6- failed 
99. Pier comments (eg. undermined penetration, protection and protection extent, unusual scour processes, etc.):

-
-
-
-
-
-
-
-
-

100.

\section{E. Downstream Channel Assessment}

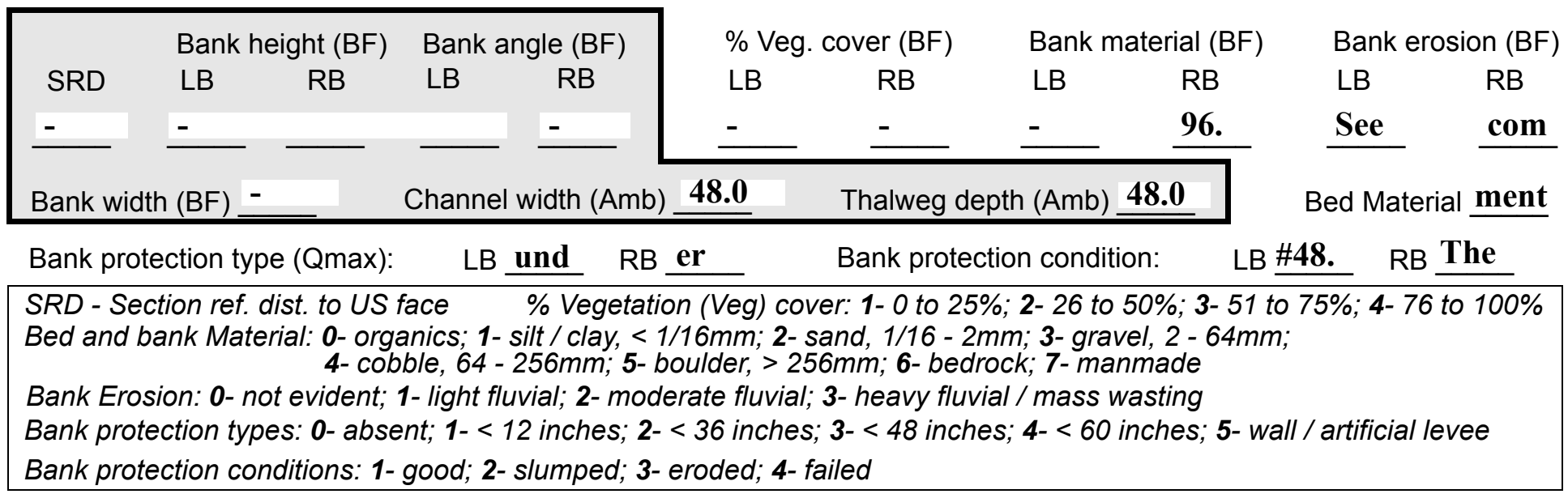

Comments (eg. bank material variation, minor inflows, protection extent, etc.):

re are 2 concrete piers. The footings are not evident on the streambed surface around either pier.

Cobbles and boulders are along the pier base.

101. Is a drop structure present? $\mathbf{2 3}$ ( $Y$ or $N$, if $N$ type ctrl-n ds) 102. Distance: ___ feet 103. Drop: -_ feet 104. Structure material: 4 (1- steel sheet pile; 2- wood pile; 3- concrete; 4- other) 105. Drop structure comments (eg. downstream scour depth): 0

0 
Point bar extent: feet

(US, UB, DS) to feet (US, UB, DS) positioned $\%$ LB to $\%$ RB

Material:

Point or side bar comments (Circle Point or Side; note additional bars, material variation, status, etc.):

$\mathbf{N}$

Is a cut-bank present? - (Y or if $N$ type ctrl-n cb) Where? NO (LB or RB) Mid-bank distance: DR Cut bank extent: $\underline{\mathbf{O P}}$ feet $\underline{\mathbf{S T}}$ (US, UB, DS) to $\underline{\mathbf{R U C}}$ feet $\underline{\mathbf{T U}}$ (US, UB, DS)

Bank damage: $\underline{\mathbf{R E}}$ (1-eroded and/or creep; 2- slip failure; 3- block failure)

Cut bank comments (eg. additional cut banks, protection condition, etc.):

Is channel scour present? ( $Y$ or if $N$ type ctrl-n cs)

Mid-scour distance: $\mathbf{N}$

Scour dimensions: Length Width Depth: -

Positioned $\%$ LB to $\%$ RB

Scour comments (eg. additional scour areas, local scouring process, etc.):

$-$

$-$

Are there major confluences? $\mathbf{N}$ (Yor if $N$ type $c t r l-n m c)$ Confluence 1: Distance POI Confluence 2: Distance RS Enters on $\mathbf{N T}$ ( $L B$ or RB)

Enters on (LB or $R B)$
How many? $\underline{\mathbf{O}}$

Type BA (1- perennial; 2- ephemeral)

Type (1- perennial; 2- ephemeral)

Confluence comments (eg. confluence name):

$\mathbf{N}$

\section{F. Geomorphic Channel Assessment}

107. Stage of reach evolution -

1- Constructed

2- Stable

3- Aggraded

4- Degraded

5- Laterally unstable

6- Vertically and laterally unstable 
108. Evolution comments (Channel evolution not considering bridge effects; See HEC-20, Figure 1 for geomorphic descriptors):

$-$

$-$

$-$

-

$-$

$-$

NO CUT BANKS

$\mathbf{N}$

$-$ 


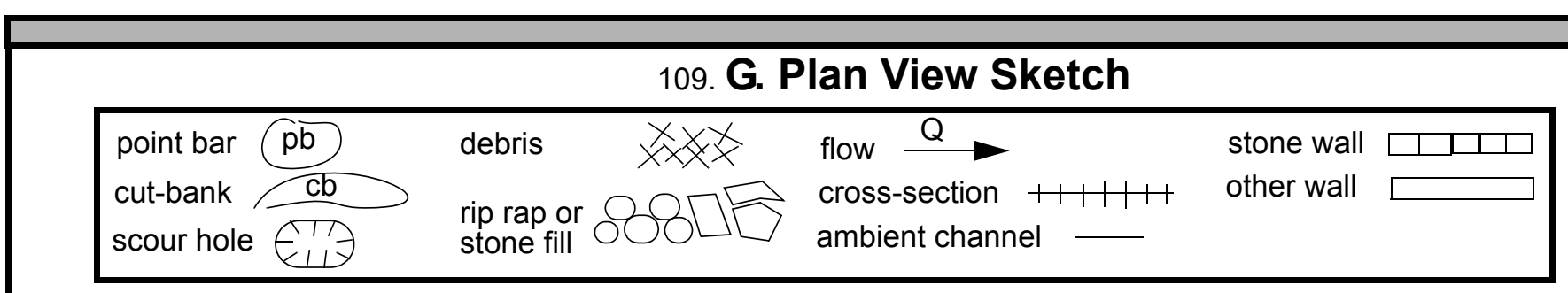


APPENDIX F:

SCOUR COMPUTATIONS 
SCOUR COMPUTATIONS

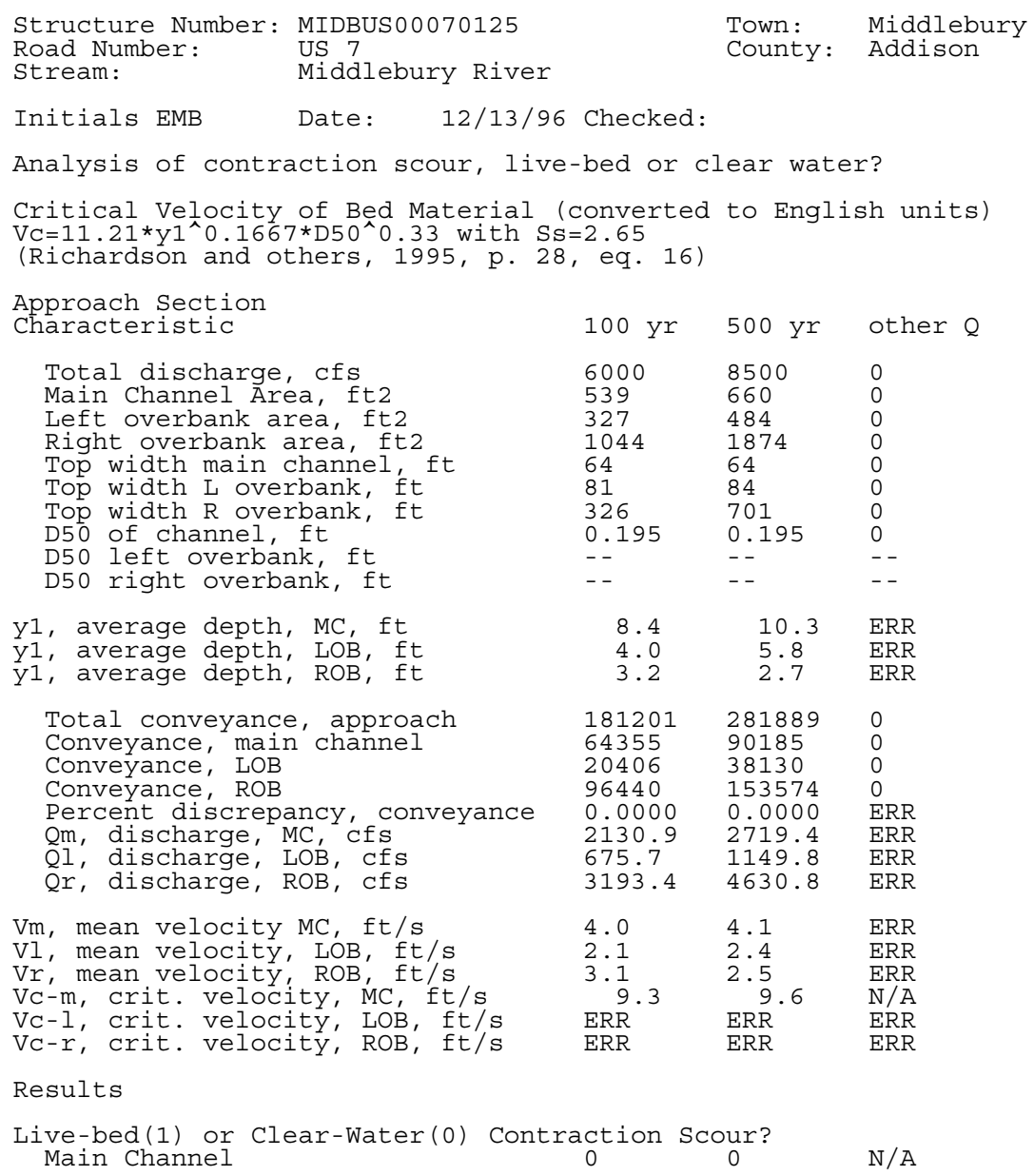


Clear water Contraction Scour in MAIN CHANNEL

\begin{tabular}{|c|c|c|c|}
\hline $\begin{array}{l}\mathrm{y}^{2}=\left(\mathrm{Q} 2^{\wedge} 2 /\left(131 * \mathrm{Dm}^{\wedge}(2 / 3) * \mathrm{~W} 2^{\wedge} 2\right)\right)^{\wedge}( \\
\mathrm{ys}=\mathrm{y} 2-\mathrm{y} \text { bridge } \\
(\mathrm{Richardson} \text { and others, } 1995, \mathrm{p} .\end{array}$ & 7) $\begin{array}{r}\text { Cor } \\
\text { eq. } 20\end{array}$ & verted tc & English \\
\hline Approach Section & Q100 & Q500 & Qother \\
\hline $\begin{array}{l}\text { Main channel Area, ft2 } \\
\text { Main channel width, ft } \\
\text { y1, main channel depth, ft }\end{array}$ & $\begin{array}{l}539 \\
64 \\
8.42\end{array}$ & $\begin{array}{l}660 \\
64 \\
10.31\end{array}$ & $\begin{array}{l}0 \\
0 \\
\text { ERR }\end{array}$ \\
\hline Bridge Section & & & \\
\hline $\begin{array}{l}\text { (Q) total discharge, cfs } \\
\text { (Q) discharge thru bridge, cfs }\end{array}$ & $\begin{array}{l}6000 \\
6000\end{array}$ & $\begin{array}{l}8500 \\
8500\end{array}$ & $\begin{array}{l}0 \\
0\end{array}$ \\
\hline $\begin{array}{l}\text { Main channel conveyance } \\
\text { Total conveyance } \\
\text { Q2, bridge MC discharge, cfs } \\
\text { Main channel area, ft2 } \\
\text { Main channel width (skewed), ft } \\
\text { Cum. width of piers in MC, ft } \\
\text { W, adjusted width, ft } \\
\text { y,bridge (avg. depth at br.), ft } \\
\text { Dm, median (1.25*D50), ft } \\
\text { y2, depth in contraction, ft }\end{array}$ & $\begin{array}{l}107686 \\
107686 \\
6000 \\
691 \\
107.8 \\
7.0 \\
100.8 \\
6.85 \\
0.24375 \\
\quad 6.15\end{array}$ & $\begin{array}{l}113823 \\
113823 \\
8500 \\
717 \\
109.2 \\
7.0 \\
102.2 \\
7.02 \\
0.24375 \\
\quad 8.19\end{array}$ & $\begin{array}{l}0 \\
0 \\
\text { ERR } \\
0 \\
0.0 \\
0.0 \\
0 \\
\text { ERR } \\
0 \\
\text { ERR }\end{array}$ \\
\hline ys, scour depth (y2-ybridge), ft & -0.70 & 1.17 & $\mathrm{~N} / \mathrm{A}$ \\
\hline $\begin{array}{l}\text { ARMORING } \\
\text { D90 } \\
\text { D95 } \\
\text { Critical grain size, Dc, ft } \\
\text { Decimal-percent coarser than DC } \\
\text { Depth to armoring, ft }\end{array}$ & $\begin{array}{l}0.3772 \\
0.4196 \\
0.2676 \\
0.286 \\
2.00\end{array}$ & $\begin{array}{l}0.3772 \\
0.4196 \\
0.4930 \\
0.03 \\
47.82\end{array}$ & $\begin{array}{l}0 \\
0 \\
\text { ERR } \\
0 \\
\text { ERR }\end{array}$ \\
\hline
\end{tabular}




\section{Abutment Scour}

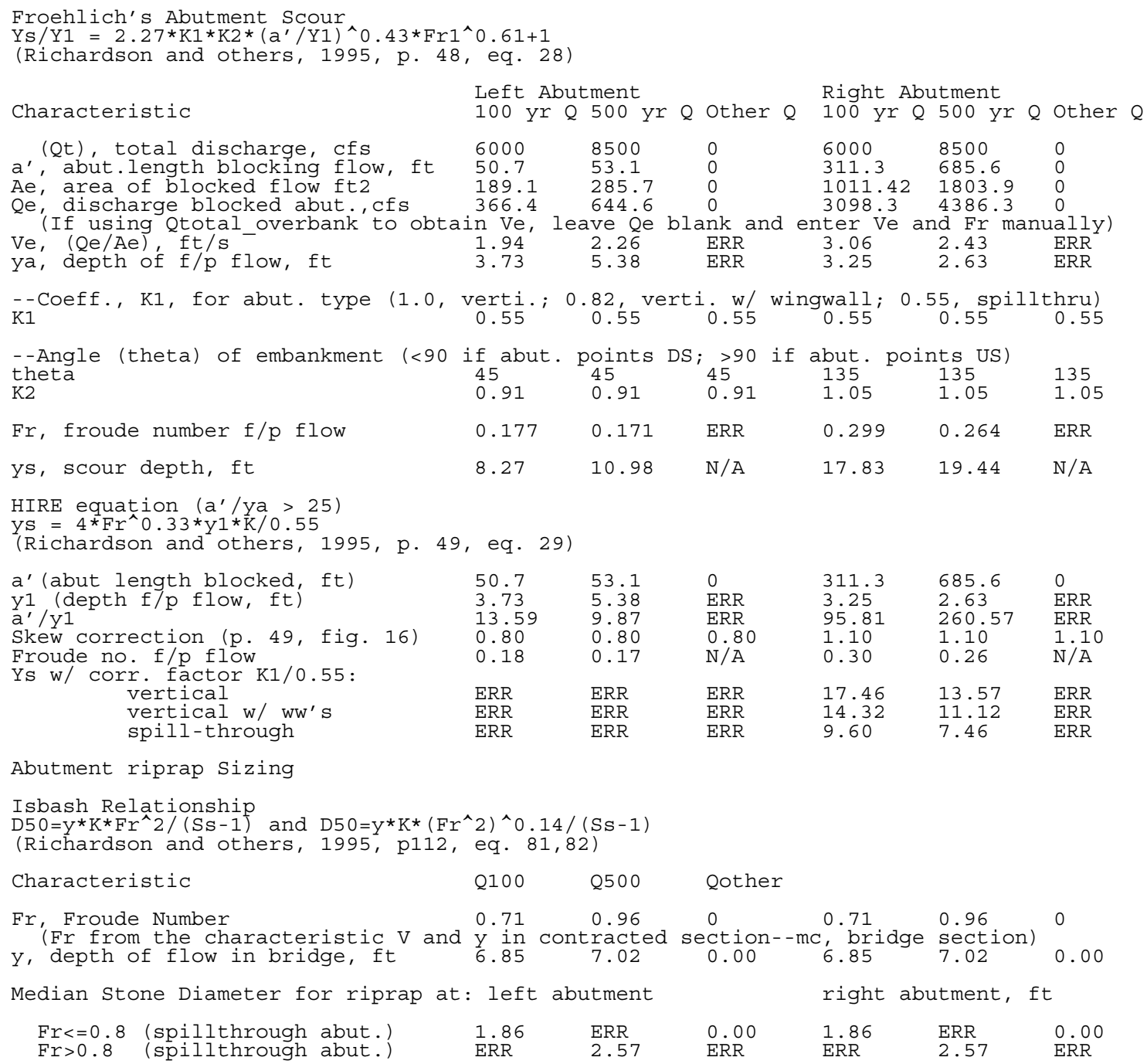




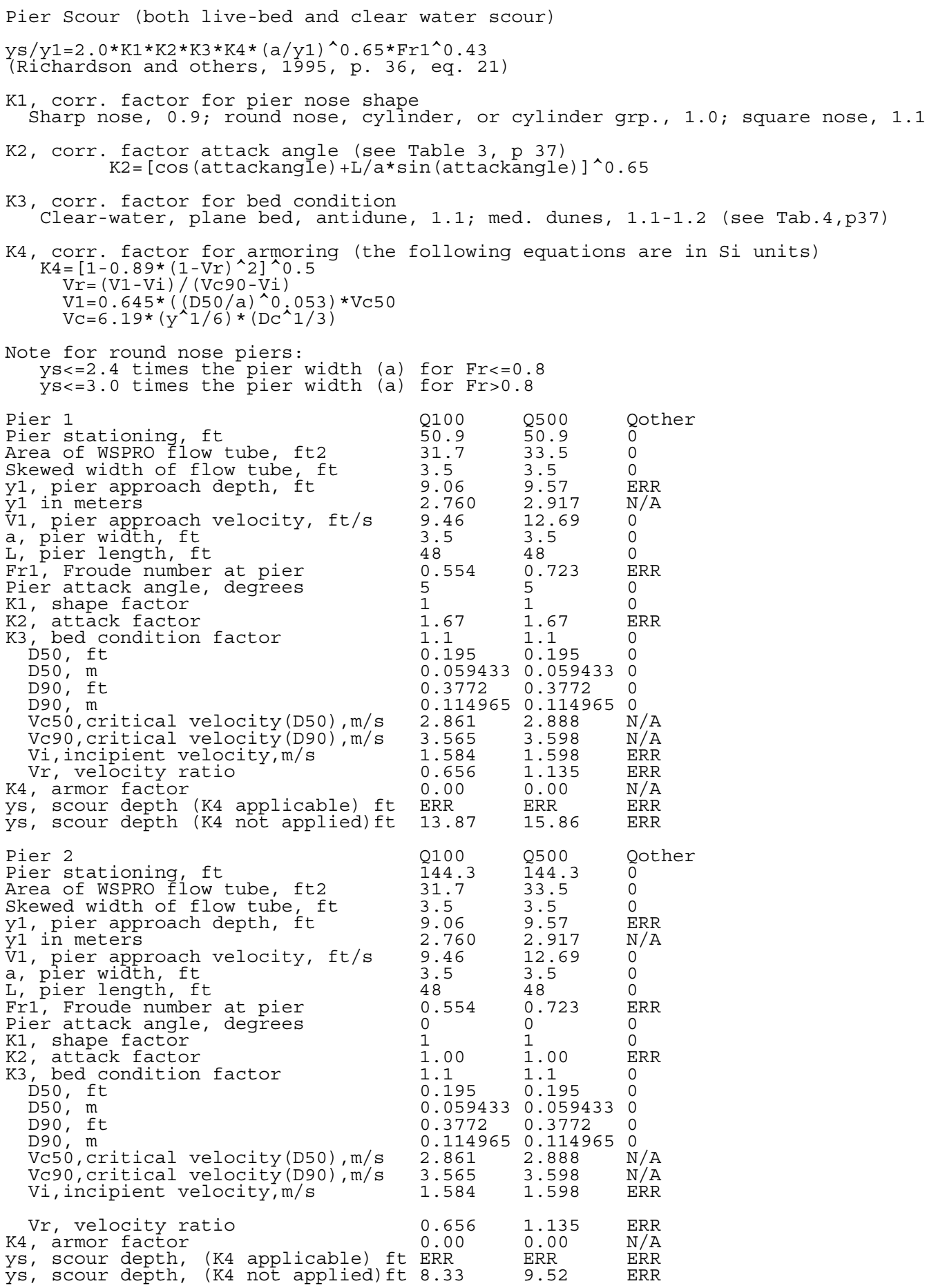

\begin{tabular}{|c|c|c|}
\hline $\begin{array}{l}059433 \\
3772 \\
114965\end{array}$ & $\begin{array}{l}\text { Q500 } \\
50.9 \\
33.5 \\
3.5 \\
9.57 \\
2.917 \\
12.69 \\
3.5 \\
48 \\
0.723 \\
5 \\
1 \\
1.67 \\
1.1 \\
0.195 \\
0.059433 \\
0.3772 \\
0.114965 \\
2.888 \\
3.598 \\
1.598 \\
1.135 \\
0.00 \\
\text { ERR } \\
15.86\end{array}$ & $\begin{array}{l}\text { Qother } \\
0 \\
0 \\
0 \\
\text { ERR } \\
\text { N/A } \\
0 \\
0 \\
0 \\
\text { ERR } \\
0 \\
0 \\
\text { ERR } \\
0 \\
0 \\
0 \\
0 \\
0 \\
\text { N/A } \\
\text { N/A } \\
\text { ERR } \\
\text { ERR } \\
\text { N/A } \\
\text { ERR } \\
\text { ERR }\end{array}$ \\
\hline $\begin{array}{l}Q 100 \\
144.3 \\
31.7 \\
3.5 \\
9.06 \\
2.760 \\
9.46 \\
3.5 \\
48 \\
0.554 \\
0 \\
1 \\
1.00 \\
1.1 \\
0.195 \\
0.059433 \\
0.3772 \\
0.114965 \\
2.861 \\
3.565 \\
1.584\end{array}$ & $\begin{array}{l}Q 500 \\
144.3 \\
33.5 \\
3.5 \\
9.57 \\
2.917 \\
12.69 \\
3.5 \\
48 \\
0.723 \\
0 \\
1 \\
1.00 \\
1.1 \\
0.195 \\
0.059433 \\
0.3772 \\
0.114965 \\
2.888 \\
3.598 \\
1.598\end{array}$ & $\begin{array}{l}\text { Qother } \\
0 \\
0 \\
0 \\
\text { ERR } \\
\text { N/A } \\
0 \\
0 \\
0 \\
\text { ERR } \\
0 \\
0 \\
\text { ERR } \\
0 \\
0 \\
0 \\
0 \\
0 \\
\text { N/A } \\
\text { N/A } \\
\text { ERR }\end{array}$ \\
\hline $\begin{array}{l}0.656 \\
0.00 \\
\text { ERR } \\
8.33\end{array}$ & $\begin{array}{l}1.135 \\
0.00 \\
\text { ERR } \\
9.52\end{array}$ & $\begin{array}{l}\text { ERR } \\
N / A \\
\text { ERR } \\
\text { ERR }\end{array}$ \\
\hline
\end{tabular}




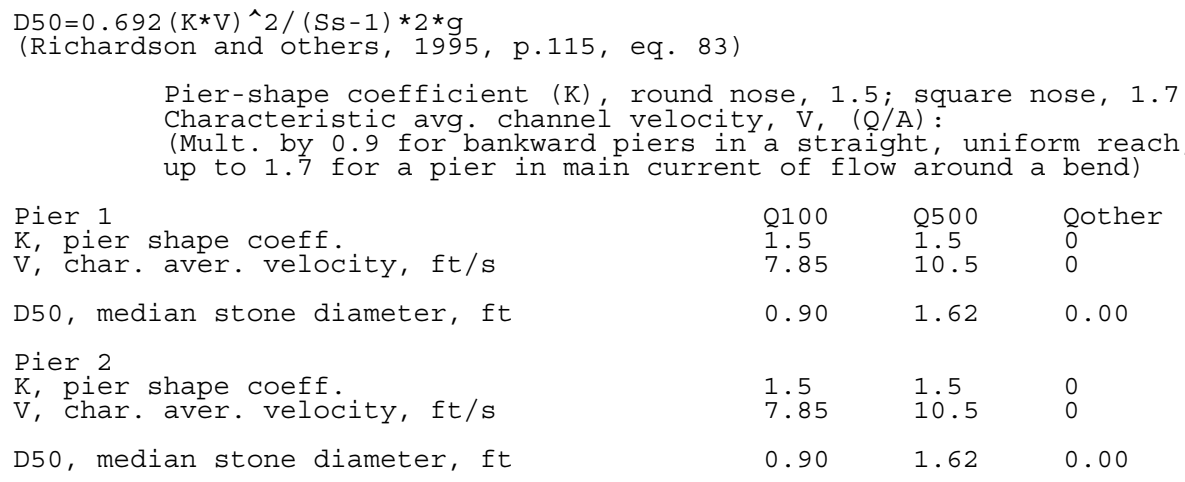

